NBER WORKING PAPER SERIES

\title{
CAN AUTOMATIC GOVERNMENT SPENDING BE PROCYCLICAL?
}

\author{
Luciana Galeano \\ Alejandro Izquierdo \\ Jorge P. Puig \\ Carlos A. Vegh \\ Guillermo Vuletin \\ Working Paper 28521 \\ http://www.nber.org/papers/w28521 \\ NATIONAL BUREAU OF ECONOMIC RESEARCH \\ 1050 Massachusetts Avenue \\ Cambridge, MA 02138 \\ March 2021
}

The authors are grateful to Martin Ardanaz, Daniel Artana, Ricardo Bebczuk, Fernando Blanco, Jessica Bracco, Antonio David, Hamid Davoodi, Luciano Di Gresia, Guillermo Falcone, Antonio Fatas, Santiago Garganta, Leonardo Gasparini, Shafaat Khan, Norman Loayza, Nicolas Magud, Fernando Navajas, Jorge Neyro, Steven Pennings, Carola Pessino, Francisco Pizzi, Luca Ricci, Daniel Riera-Crichton, Diego Rojas, Adolfo Sturzenegger, and seminar participants at the World Bank, International Monetary Fund, and Universidad Nacional de La Plata (Argentina) for helpful comments and suggestions. We are also grateful to Maria Teresa Balestrini, Jose Andree Camarena, Guillermo Falcone, Sabrina Lozano, Jorge Miranda, Luis Morano, and Lucila Venturi for excellent research assistance. The views expressed herein are those of the authors and do not necessarily reflect the views of the National Bureau of Economic Research.

NBER working papers are circulated for discussion and comment purposes. They have not been peer-reviewed or been subject to the review by the NBER Board of Directors that accompanies official NBER publications.

(C) 2021 by Luciana Galeano, Alejandro Izquierdo, Jorge P. Puig, Carlos A. Vegh, and Guillermo Vuletin. All rights reserved. Short sections of text, not to exceed two paragraphs, may be quoted without explicit permission provided that full credit, including () notice, is given to the source. 
Can Automatic Government Spending Be Procyclical?

Luciana Galeano, Alejandro Izquierdo, Jorge P. Puig, Carlos A. Vegh, and Guillermo Vuletin NBER Working Paper No. 28521

March 2021

JEL No. E02,E32,E62,H53,H55

\section{ABSTRACT}

It is well-known by now that government spending has typically been countercyclical in industrial countries and procyclical in developing economies. Most of this literature has focused on analyzing aggregate government spending or discretionary spending categories such as government consumption and government investment. Little is known, however, about the cyclical behavior of automatic government spending, which comprises unemployment insurance, family programs, and social security transfers. Automatic government spending follows from laws, or even constitutional clauses, that benefit individuals who meet certain eligibility criteria. In principle, the main categories of automatic government spending are expected to be either countercyclical (especially unemployment insurance and other shock absorber programs) or acyclical (particularly social security and other structural programs).

We find that while automatic government spending is, as expected, countercyclical in industrial countries, it is, surprisingly, procyclical in the developing world. We track the source of this puzzling procyclical behavior to (i) the effective lack of automatic stabilizers like unemployment insurance and (ii) more intriguingly, the existence of perverse automatic de-stabilizing mechanisms in social security spending (in particular in the absence of indexation mechanisms). We also show that the presence and nature of these two social programs are crucial new determinants of aggregate government spending cyclicality as well as macroeconomic volatility, even after controlling for other well-known determinants and addressing potential endogeneity concerns.

Luciana Galeano

University of Michigan

611 Tappan Ave

Ann Arbor, MI 48109

United States

lgaleano@umich.edu

Alejandro Izquierdo

Inter-American Development Bank

1300 New York Ave, N. W.

Washington, D. C., 20577

alejandroi@iadb.org

Jorge P. Puig

FCE-Universidad Nacional de La Plata

Calle 6 \#777

La Plata, 1900

Argentina

jorge.puig@econo.unlp.edu.ar
Carlos A. Vegh

School of Advanced International Studies (SAIS)

Johns Hopkins University

1717 Massachusetts Avenue, NW

Washington, DC 20036

and NBER

cvegh1@jhu.edu

Guillermo Vuletin

The World Bank

1818 H Street NW

Washington, DC 20433

gvuletin@worldbank.org 


\section{Introduction}

Contrary to economists' prescriptions and the typical behavior in the industrial world, government spending in developing countries has been, by and large, procyclical (e.g., Gavin and Perotti, 1997; Kaminsky, Reinhart, and Vegh, 2004; Alesina, Campante, and Tabellini, 2008; Frankel, Vegh, and Vuletin, 2013). ${ }^{1}$ Procyclical fiscal policies that increase spending in good times and cut it in bad times tend to amplify output fluctuations, leading to large social costs, especially for the most vulnerable (e.g., Fatas and Mihov, 2003, 2012; Vegh and Vuletin, 2014a, 2014b). The opposite is true in the case of countercyclical policies, which help to smooth out output fluctuations and, thus, protect social gains (e.g., Loayza et al., 2007; Camarena et al. 2019).

Figure 1 - an updated version of Frankel, Vegh, and Vuletin (2013) - illustrates this phenomenon by plotting the correlation between the cyclical components of real GDP and real government spending (primary spending, to be precise) for 131 countries during the period 1980-2018. Yellow bars stand for developing countries while black bars indicate industrial economies. The visual impression is striking: while a majority of black bars lie to the left of the figure, indicating a negative correlation and hence countercyclical spending in industrial economies, the majority of yellow bars lie to the right, indicating a positive correlation and hence procyclical spending in developing economies. ${ }^{2}$ In fact, the correlation is 0.35 for developing countries and -0.08 for industrial countries, in both cases statistically significant (see also "primary spending" box in Figure 2).

\section{FIGURES 1 AND 2}

Several hypothesis have been put forth in the literature to explain procyclical government spending, ranging from limited access to international credit markets (e.g., Riascos and Vegh, 2003; Cuadra, Sanchez, and Sapriza, 2010; Bianchi, Ottonello, Presno, 2019) to political economy distortions, institutional weaknesses, and over-optimism (e.g., Tornell and Lane, 1999; Talvi and Vegh, 2005; Woo, 2009; Frankel, 2011; Frankel, Vegh, and Vuletin, 2013; Avellan and Vuletin, 2015) which, in turn, generate "excessive" public spending during boom periods and "force" policymakers to cut spending in bad times.

By and large, the literature on the behavior of government spending over the business cycle has focused on aggregate government spending. Aggregate in the sense of having in mind some homogeneous good on the theoretical front and relying on measures such as primary government spending on the empirical front. Studies on the cyclical properties of specific government spending categories have mainly focused on government consumption and government investment (e.g., Kaminsky, Rein-

\footnotetext{
${ }^{1}$ On the taxation side (i.e., using tax rate data), Vegh and Vuletin (2015) also find that procyclicality has been the norm in the developing world.

${ }^{2}$ Needless to say, correlations do not tell us anything about causality which, in principle, could go in either direction. However, Ilzetzki and Vegh (2008) and Frankel, Vegh, and Vuletin (2013) show that, even when properly instrumented, output fluctuations cause government spending changes, as emphasized by the fiscal procyclicality literature.
} 
hart, and Vegh, 2004; Talvi and Vegh, 2005; Ilzetzki and Vegh, 2008; Ardanaz and Izquierdo, 2017; Izquierdo, Pessino, and Vuletin, 2018). In terms of government consumption (which includes mainly wages and salaries and goods and services), the evidence indicates acyclicality in industrial countries and procyclicality in developing economies. ${ }^{3}$ As to government investment, the findings support countercyclicality in industrial economies and procyclicality in developing countries. ${ }^{4}$ Interestingly, both government consumption and government investment are discretionary in nature, in the sense that they are the direct result of policymakers' deliberate spending decisions when approving the budget.

In contrast, little is known, particularly in the developing world, about the cyclical behavior of automatic spending, defined as spending not directly related to policymakers' deliberate/discretionary decisions. Automatic spending, in most cases cash transfers to individuals or households, involves the disbursement of public funds resulting from laws (and, even, constitutional mandates), benefiting individuals who meet certain eligibility criteria. The specific nature/type of social programs is, naturally, shaped by countries' most pressing social challenges. The most important automatic spending categories include (i) unemployment insurance (transfers to unemployed individuals), (ii) family programs and benefits, which include conditional cash transfers mainly to the poor and most vulnerable households, and (iii) social security (mainly transfers to individuals after retirement). ${ }^{5}$

Interestingly, while unemployment insurance and other shock absorbing programs are rightly expected to be countercyclical, the cyclicality of social security and other structural social programs is much less obvious. In fact, recent work on the effects of fiscal spending (especially of automatic nature) on macroeconomic volatility in the U.S. and Europe has focused on automatic stabilizers such as unemployment insurance, explicitly excluding social security from the analysis (e.g., McKay and Reis, 2016; Di Maggio and Kermani, 2016; Krueger, Mitman, Perri, 2016). Arguably, the reason is that, unlike unemployment insurance and other shock absorbing social programs, social

\footnotetext{
${ }^{3}$ Since, by and large, wages and salaries and goods and services spending lie behind the provision of key public goods such as education, health, police, and defense, it is not surprising to find acyclicality in industrial countries. After all, it is not obvious why governments would change, for example, the number of teachers, doctors, policeman, or military personnel over the business cycle. In principle such decisions should be related to social preferences and the specific properties of public goods production. In contrast, it is quite common in developing countries for public wages and public workers to increase in good times, reflecting the cyclical abundance of public resources and fall in bad times as part of needed fiscal adjustments. See, for example, Freeman (1987), Kraay and van Rijckeghem (1995) and Eckardt and Mills (2014) for more details on this cyclical aspect of spending.

${ }^{4}$ Countercyclical government investment in the industrial world is consistent with standard Keynesian arguments. In fact, Keynes felt so strongly about the stabilizing role of government investment that he was of the view that budget policy should have an "ordinary budget" and a "capital budget" (Brown-Collier and Collier, 1995). The procyclical profile found in the developing world responds mainly to (i) the convenience of fiscally adjusting in bad times by cutting pubic investment (Ardanaz and Izquierdo, 2017) and (ii) the low levels of trust and lack of commitment to long-term projects in the developing world, which generates a bias against government investment (Izquierdo, Pessino, and Vuletin, 2018).

${ }^{5}$ Social security also comprises transfers to disabled individuals, and families of retired, disabled, or deceased workers. However, old age spending represents, by and large, the most important sub-category of spending. For example, and based on data for 39 countries (20 developing and 19 industrial), the share of old age expenditure represents 72.4 percent of total social security spending (76 percent for developing countries and 70 percent for industrial countries).
} 
security transfers are not expected to be systematically related to business cycle fluctuations since the underlying criterion for those transfers is determined by slow-moving demographic trends (i.e., one would expect a zero correlation between short-term changes in social security spending and output fluctuations). Actually, most of the attention in academic and policy circles regarding fiscal aspects of social security systems has been dominated by how the intrinsically structural/rigid nature of these entitlement programs coupled with falling birth rates and population aging, especially in pay-as-you-go systems, poses unique and growing fiscal sustainability challenges for social security systems around the world (e.g., Fichtner, 2018; Izquierdo, Pessino, and Vuletin, 2018; Chomik, Piggott, and Yan, 2019).

This paper focuses on the nature of government primary spending over the business cycle by distinguishing between discretionary and automatic spending. The analysis unveils structural deficiencies in the developing world, not only in discretionary spending (which is procyclical), but, more novel and intriguing, in automatic spending. Naturally, we are not the first ones to explore, with varying degrees of explicitness, the cyclical properties of non-discretionary components of government spending (e.g., Kaminsky, Reinhart, and Vegh, 2004; Ilzetzki and Vegh, 2008; Michaud and Rothert, 2018). ${ }^{6}$ However, none of these papers focuses on the cyclicality of automatic spending per se and/or look into the cyclicality of different components of automatic spending.

We find that, indeed, while countercyclical in industrial countries, automatic spending is procyclical in the developing world. This procyclical behavior constitutes a puzzle because most important automatic spending categories should (i.e., in theory) be either countercyclical (especially unemployment insurance and other shock absorbing social programs) or acyclical (especially social security and other structural social programs). Therefore, automatic spending should (i.e., in theory) never be procyclical! The observed procyclicality in automatic spending in the developing world, however, compromises the ability of automatic spending policies to effectively act as stabilizers. In fact, they act as de-stabilizers! Put differently, the procyclical behavior of automatic spending severely limits the ability to protect the most vulnerable and reduce macroeconomic volatility.

Using off-the-shelf macro-spending and novel micro-spending data, we trace the roots of this automatic spending procyclical puzzle in developing countries. We find that it emerges as the result of (i) lack of automatic stabilizers (due mainly to the absence, or negligible coverage, of shock absorbers like unemployment insurance) and (ii) more intriguingly, the existence of perverse automatic de-stabilizing mechanisms, particularly due to the way in which individual social security benefit payments fluctuate over time in the developing world. When formula-based indexation mechanisms (typically linked to changes in cost of living like prices or nominal wages) lie behind

\footnotetext{
${ }^{6}$ In particular, and based on 30 countries, Michaud and Rothert (2018) show that social transfers are countercyclical in industrial countries and procyclical in developing ones and then turn to the quantitative implications on consumption volatility in emerging markets.
} 
social security payments, social security spending is indeed acyclical. However, when such decisions rely on policymakers' ad-hoc/discretionary criteria, individual social security benefit payments tend to be linked, in practice, to the revenue capacity of the social security system which, by its very nature, comoves positively with output. Since the lack of formula-based indexation mechanisms is much more pervasive in developing economies, the procyclical bias behind the automatic spending procyclical puzzle is due to the behavior of social security spending in the developing world.

The identification and understanding of this automatic spending procyclical puzzle is extremely relevant for several reasons. First, it allows for a better understanding of the macroeconomic effects of automatic spending policy on macroeconomic volatility, not only through the favorable lenses of automatic stabilizers such as unemployment insurance schemes (e.g., Spilimbergo et al., 2010; Blanchard, Dell'Ariccia, and Mauro, 2010), but also through the lenses of de-stabilizing spending forces of automatic nature. Second, this automatic spending procyclical puzzle should be helpful in contextualizing and reshaping the discussion on the merits of discretionary versus automatic fiscal policy (Fatas and Mihov, 2001, 2003; Blanchard, 2006). In other words, our new evidence suggests that de-stabilizing forces, especially in the developing world, may come from both discretionary spending (e.g., procyclical wage bill or government investment) and automatic spending (via social security spending). Third, it is worth recalling that social security is a mayor spending item. Figure 3 shows the importance of each spending category in industrial and developing countries as percentage of primary government spending. Social security represents (i) 43 percent of primary spending in industrial countries and 32.5 percent in developing economies (see "social security" box in Figure 3), (ii) 75 percent of automatic spending in the industrial world and 80 percent in developing countries (comparing values of "social security" and "automatic spending" boxes in Figure 3), and (iii) almost as much as public consumption (comparing values of "social security" and "government consumption" boxes in Figure 3). Moreover, given falling birth rates and aging population, it is expected (in absence of social security reforms) that social security spending could grow between 2 and 5-fold in the next 40 years (e.g., Bongaarts, 2004; Nerlich and Schroth, 2018; Panadeiros and Pessino, 2018).

\section{FIGURE 3}

The paper proceeds as follows. Section 2 first presents basic empirical stylized facts on the cyclical properties of discretionary and automatic spending for industrial and developing countries. We then turn to a detailed analysis of the cyclical considerations of the most important automatic spending categories. Section 3 shows that, as expected, unemployment insurance spending is overwhelmingly countercyclical both in industrial and developing countries (mainly due to large short-term fluctuations in the number of beneficiaries). However, this type of program is uncommon in the developing world. Only 40 percent of developing countries currently have it and, even when present, its coverage is negligible. This shortcoming helps to explain the lack of countercyclicality 
observed in automatic spending in the developing world. Section 4 shows that family programs are very structural/rigid in nature and, as expected, overwhelmingly acyclical both in industrial and developing countries. Section 5 shows that the procyclical force behind the automatic spending procyclical puzzle originates in the behavior of social security spending and, in particular,s in the lack of formula-based indexation mechanisms and the reliance upon policymakers' ad-hoc/discretionary criteria to adjust individual social security benefit payments. After this detailed analysis of the most important automatic spending categories, Section 6 shows that the presence of automatic spending of stabilizing (or de-stabilizing!) nature like unemployment insurance and social security formula-based indexation mechanisms are, indeed, important new determinants of aggregate government spending cyclicality (primary spending, to be precise), even after controlling for other well-known determinants and addressing potential endogeneity concerns. Section 7 revisits the merits of government spending as a macroeconomic stabilizer. It finds that the importance of government size, especially of its automatic government spending component, as a stabilizing force found in previous studies (e.g., Fatas and Mihov, 2001, 2003) mainly depends on the presence of unemployment insurance and social security formula-based indexation mechanisms. Concluding remarks can be found in Section 8 .

\section{Cyclicality of discretionary and automatic spending: Basic styl- ized facts}

Using off-the-shelf macro-spending data, we now analyze the cyclicality of discretionary spending (which comprises government consumption and government investment) and automatic spending (proxied by transfers to individuals and households that mainly include unemployment insurance, family programs, and social security).

Figure 4 shows, like Figure 1, the degree of cyclicality in government spending, this time focusing solely on discretionary spending. Industrial countries follow an acyclical profile and developing economies behave procyclically (see also "discretionary spending" box in Figure 2). This evidence is in line with previous studies focusing on government consumption and government investment (e.g., Kaminsky, Reinhart, and Vegh, 2004; Talvi and Vegh, 2005; Ilzetzki and Vegh, 2008; Ardanaz and Izquierdo, 2017; Izquierdo, Pessino, and Vuletin, 2018). ${ }^{7}$

\section{FIGURE 4}

\footnotetext{
${ }^{7}$ For brevity's sake, and since they are not the focus of our analysis, we do not show country-based cyclicality correlation figures for public investment and public consumption. Having said that, it is worth noting that, in line with previous studies, we also find that (i) government investment is countercyclical in industrial countries and procyclical in developing countries and (ii) government consumption is acyclical in industrial countries and procyclical in developing countries (see "government investment" and "government consumption" boxes in Figure 2).
} 
We now turn our attention to automatic spending. Figure 5 shows, like Figure 1, the degree of cyclicality in spending, this time focusing solely on automatic spending. Much like in Figure 1, automatic spending is countercyclical in industrial countries (with a statistically significant correlation of -0.27) and procyclical in the developing world (with a statistically significant correlation of 0.19). (See also "automatic spending" box in Figure 2.) Hence, while there is countercyclical behavior in industrial countries (driven by automatic spending), the developing world exhibits a procyclical profile (driven by both discretionary and automatic spending).

\section{FIGURE 5}

As discussed in the Introduction, it is truly a puzzle how automatic spending could be procyclical, when most important automatic spending categories should, in theory, be either acyclical or countercyclical. We now turn to a detailed analysis of the cyclical considerations behind the most important automatic spending categories.

\section{Unemployment insurance: A poster child of countercyclicality that is rare in the developing world}

Unemployment insurance is, by design, the poster child of automatic stabilizers. In other words, it is the textbook example of a countercyclical spending policy that, by construction, offsets output movements. In countries with unemployment insurance, workers that lose their jobs during a recession receive transfers to compensate for the loss of income. As the economy recovers, the unemployed return to work and stop receiving these transfers. ${ }^{8}$

Using a novel micro-spending dataset for Latin America and the Caribbean and existing data from OECD countries, we put together a database on unemployment insurance spending for 25 countries (10 developing and 15 industrial) for the period 1980-2015. Moreover, for 20 of these countries, we could also break down such spending into (i) the number of beneficiaries and (ii) the average spending per beneficiary. ${ }^{9}$ This micro-spending data tells us that unemployment insurance spending represents about 7 percent of automatic spending and 4 percent of primary spending in the industrial world, but a mere 1 percent and 0.5 percent, respectively, in developing countries (see also "unemployment insurance" box in Figure 3).

Figure 6 shows the cyclicality of unemployment insurance spending. Unlike Figures 1, 4, and 5 , unemployment insurance spending is overwhelmingly countercyclical both in the industrial and

\footnotetext{
${ }^{8}$ Naturally, the specifics of the unemployment insurance program, including the type of unemployed workers entitled to benefits, the maximum time they are allowed to receive benefits, the source of funding, and the conditions under which these benefits are to be maintained vary across countries (e.g., Ribe, Robalino, and Walker, 2012; Cerutti et al., 2014; Asenjo and Pignatti, 2019).

${ }^{9}$ See Appendix 3 for details.
} 
developing world. The correlation is -0.55 for developing economies and -0.51 for industrial countries (in both cases statistically significant). (See also "unemployment insurance" box in Figure 2.) In fact, we cannot reject the null hypothesis that both correlations are statistically the same. Further, and based on individual country correlations and statistical significance, all industrial and developing countries follow countercyclical unemployment insurance spending.

\section{FIGURE 6}

To better understand the mechanism at work, we decompose unemployment insurance spending into "q versus p," so to speak, where "q" represents the number of unemployment insurance beneficiaries and "p" the average real spending per beneficiary. Panel A in Figure 7 shows the cyclicality of the number of unemployment insurance beneficiaries and Panel $\mathrm{B}$ the equivalent figure for the average real spending per beneficiary. Much like Figure 6, Panel A in Figure 7 shows that the cyclicality of the number of unemployment insurance beneficiaries is overwhelmingly countercyclical, both in the industrial and developing world. The correlation is -0.59 for developing economies and -0.72 for industrial countries (in both cases statistically significant). In fact, we cannot reject the null hypothesis that both correlations are statistically the same. Moreover, and based on individual country correlations and statistical significance, about 90 percent of industrial and developing countries follow a countercyclical behavior in the number of unemployment insurance beneficiaries.

In contrast, the evidence from Panel B in Figure 7 shows that the average real spending per beneficiary is, by and large, acyclical. The correlation is 0.08 for developing economies and -0.14 for industrial countries (and in both cases not statistically significant). Moreover, and based on individual country correlations and statistical significance, about 80 percent of industrial and 90 percent of developing countries follow an acyclical behavior regarding the average real spending per beneficiary.

\section{FIGURE 7}

It is also interesting to note that, when performing a simple univariate variance decomposition analysis, on average, about 83 percent of the variance of unemployment insurance real spending can be explained by its cyclical component and only 17 percent is driven by its trend. As a reference, for real primary spending, these proportions are virtually reversed. This shows the highly shortterm fluctuating nature of unemployment insurance real spending. When focusing on the equivalent figures for the number of unemployment insurance beneficiaries and the average real spending per beneficiary, we find, on average, that the share explained by their respective cyclical components are 78 percent and 22 percent, respectively.

Hence, the analysis shows that the large short-term fluctuations in unemployment insurance real spending (of a countercyclical nature) are driven by large changes in the number of unemployment 
insurance beneficiaries (of a countercyclical nature) and not by the more structural/rigid profile exhibited by the average real spending per beneficiary (which is overwhelmingly acyclical). In other words, unemployment insurance programs work in practice as would be predicted by theoretical considerations both in developing and industrial countries; that is, in a stabilizing (i.e., countercyclical) fashion mainly due to cyclical changes in the number of unemployed workers claiming those benefits.

\subsection{Unemployment insurance is rare in the developing world}

In contrast to the developing world's long history of social protection in terms of social security and the most recent wave of family programs, particularly conditional cash transfers, unemployment insurance programs are rather uncommon in developing countries. Typically, they simply do not exist or, if they do, have negligible coverage. More specifically:

- Existence of unemployment insurance mechanisms. Based on information collected mainly from the International Labour Organization (ILO) and the United States Social Security Administration, Figure 8 shows whether unemployment insurance mechanisms are present (red color) or absent (white color) in every country in the world. All industrial countries have unemployment insurances typically dating back to the Great Depression of 1929 . In contrast, only 40 percent (or 43 out of 109) of developing countries currently have some sort of unemployment insurance mechanism. ${ }^{10}$

\section{FIGURE 8}

- Effective unemployment insurance mechanism coverage. Using information from (i) ILO, regarding the ratio of unemployed individuals covered by the unemployment insurance program (i.e., extensive margin) and from (ii) Aleksynska and Schindler (2011) regarding the unemployment insurance gross replacement rate, which is defined as the ratio of unemployment insurance benefits a worker receives relative to the worker's last gross earning (i.e., intensive margin), we create a measure of effective unemployment insurance mechanism coverage defined as the product of the extensive and intensive margins. This effective measure ranges between 0 (no income replacement for any unemployed workers) and 100 (all unemployed workers receive a benefit equal to their last income). This new measure is presented in Figure 9 for countries with some unemployment insurance mechanism. In the developing world, the effective unemployment insurance mechanism coverage is 7 percent, statistically significantly lower than that of the industrial world, which is about 4 times larger (27 percent). In other words, while about 40 percent of developing countries do have some unemployment insurance

\footnotetext{
${ }^{10}$ See Appendix 3 for details.
} 
programs, their effective coverage is (unlike the industrial world) negligible.

\section{FIGURE 9}

The critical question is thus: why does the developing world lag behind on the provision of such an important shock absorber like unemployment insurance? This is particularly relevant for developing countries given that they are inherently more volatile than their industrial counterparts. While several explanations come to mind, a prime and perennial suspect is the presence of a large informal economy (Bosch and Esteban-Pretel, 2015; Duval and Loungani, 2019; Asenjo and Pignatti; 2019). In effect, a large informal share of workers makes unemployment insurance impractical due to moral hazard considerations, as the unemployed may work in the informal sector while receiving unemployment insurance benefits (Hopenhayn and Nicolini, 1997; Alvarez-Parra and Sanchez, 2009). Specifically, if workers can accept jobs in the informal sector while continuing to receive unemployment insurance benefits without being detected by the government, a more generous unemployment insurance system would reduce the incentive to search for a formal job and induce workers to accept informal jobs (Gonzalez-Rozada and Ruffo, 2016). Indeed, Figure 10 shows, using cross-sectional data for 41 countries with some type of unemployment insurance program, that higher informality is strongly associated with lower effective unemployment insurance coverage. ${ }^{11}$ Interestingly, and in line with the proposed logic, the degree of informality in countries not having any type of unemployment insurance mechanism is much larger than that observed in countries with unemployment insurance (even for those in the developing world). For example, using data circa 2010, countries without unemployment insurance have an informal sector twice as large as that in economies with some sort of unemployment insurance mechanism (36 percent compared to 18 percent, with the difference being statistically significant).

\section{FIGURE 10}

In sum, while unemployment insurance programs work in practice as predicted by theory (i.e., countercyclically) both in developing and industrial countries, the absence, or negligible coverage, of such programs in developing countries helps to explain the lack of countercyclicality observed in automatic spending in the developing world (recall Figure 5 from Section 2 and the "automatic spending" box in Figure 2).

\footnotetext{
${ }^{11}$ Figure 10 covers 41 countries. Strictly speaking, we use the concept of shadow economy (from Medina and Schneider, 2018) because labor market informality measures are only available for a much smaller set of countries. For example, if we used data from ILO focusing on labor informality, only six countries would be available. Having said that, the relationship between such a measure and effective unemployment insurance coverage is also strongly negative with an $R^{2}$ of 0.43 .
} 


\section{Family programs and benefits: As structural as it can get}

Family programs comprise a myriad of social programs typically targeting structural and deeprooted social problems that are expected to change slowly over time and should, in principle, not be related to the business cycle. A large fraction of these programs include, particularly in the developing world, conditional cash transfers. These transfers target poor households and are conditional on investing in childrens' human capital and health, or other desired policy target. For example, in Brazil, the Bolsa Familia social program provides financial aid to poor Brazilian families and, if they have children, families must ensure that the children attend school and are vaccinated. Moreover, if social vulnerability (broadly defined) tended to increase in bad times, then these type of transfers could even become countercyclical (but should certainly never be procyclical!).

For the purpose of our cyclicality analysis, and using micro-fiscal data from the Economic Commission for Latin America and the Caribbean (ECLAC), we put together a database for 35 countries (20 developing and 15 industrial) on family programs and benefits spending. ${ }^{12}$ These programs and benefits represent about 20 percent of automatic spending in the developing world and about 19 percent in industrial countries. In terms of the relevance of family programs spending as percent of primary spending, it represents 11 percent and 8 percent in industrial and developing countries, respectively (see also "family programs" box in Figure 3). It is worth noting that this gap is much smaller than that for unemployment insurance spending. For 13 countries from Latin America and the Caribbean, we could also decompose such real spending into the number of beneficiaries and the average real spending per beneficiary.

Figure 11 shows the cyclicality of family programs spending. Given that this type of spending targets structural and deep-rooted social problems that are expected to change slowly over time, family programs spending is largely acyciclical, both in industrial and developing countries. The correlation is -0.02 both in developing and industrial economies (in both cases not statistically significant). Naturally, we cannot reject the null hypothesis that both correlations are statistically the same (see also "family programs" box in Figure 2). Moreover, and based on individual country correlations and statistical significance, all industrial and 88 percent of developing countries exhibit acyclical family programs spending. Panels A and B in Figure 12 show that, by and large, the same profile, unrelated to the business cycle, is present when looking at family programs beneficiaries and spending per beneficiary in 13 LAC countries.

\section{FIGURES 11 AND 12}

Moreover, when performing a simple univariate variance decomposition analysis, on average, about 15 percent of the variance of family programs and benefits real spending can be explained by

\footnotetext{
${ }^{12}$ See Appendix 4 for details.
} 
its cyclical component and 85 percent is driven by its trend. This is virtually the opposite of unemployment insurance real spending, where 83 percent was explained by its cyclical component and only 17 percent by its trend. When focusing on the equivalent figures for the number of family programs beneficiaries and the average real spending per beneficiary, we find, on average, that the share explained by their respective trend components are 74 percent and 60 percent, respectively.

In sum, family programs spending and the number of beneficiaries are acyclical across the board and largely driven by long-term considerations. In other words, they work in practice as predicted by theory both in developing and industrial countries, trying to address structural and deep-rooted social problems that are expected to change slowly over time and are unrelated to the business cycle.

\section{Social security: Source of the procyclical anomaly}

So far, the evidence shown in Section 3 regarding the absence or negligible coverage of unemployment insurance in the developing world helps to explain the lack of countercyclicality observed in automatic spending in the developing world. However, neither this type of automatic spending, nor family programs (given their acyclical nature discussed in Section 4) can help to explain the procyclical nature of automatic spending encountered in large parts of the developing world. This section shows that the source of this procyclical anomaly of automatic spending in developing countries is based on the behavior of social security spending. As already noted, social security spending represents, by and large, the largest component of automatic spending in the industrial and developing world. Specifically, social security spending represents almost 75 percent of automatic spending in the industrial world and 80 percent in developing countries. As a percentage of primary spending, social security accounts for 43 percent and 32.5 percent in industrial and developing countries, respectively (see also "social security" box in Figure 3). It is worth noting that this gap is much smaller than that for unemployment insurance spending.

Using some off-the-shelf macro-spending and based on social security agencies websites, we put together a database for 45 countries (27 developing and 18 industrial) for the period 1980-2018 on social security spending. For 25 of these countries (18 industrial and 7 developing), we were also able to decompose such spending into the number of social security beneficiaries and the average spending per beneficiary. As will become clear below, we also collected social security revenue data from social security agencies' websites. ${ }^{13}$

Before turning to cyclicality considerations, it is worth noting that when performing a simple univariate variance decomposition analysis, on average, about 12 percent of the variance of social security real spending can be explained by its cyclical component and 88 percent is driven by its trend. These figures are very close to those obtained for family programs real spending. Interest-

\footnotetext{
${ }^{13}$ See Appendix 5 for details.
} 
ingly, when focusing on social security beneficiaries, the share explained by its trend increases to 95 percent. This latter fact holds for both industrial and developing countries (96 and 94 percent, respectively). To help put things into perspective, recall that even for the number of family programs and benefits beneficiaries (Section 4), the share explained by its trend is "only" 74 percent. The fact that fluctuations in social security beneficiaries is virtually explained solely by its trend reflects the intrinsically structural/rigid nature of beneficiaries entitled to this program, which is mainly driven by slowly-moving demographic considerations. It also indicates that cyclical fluctuations in social security real spending (our main object of interest in this section) are mainly driven by cyclical fluctuations in average social security spending per beneficiary as opposed to cyclical movements in the number of social security beneficiaries (which are virtually non-existent). In fact, the share of social security real spending per beneficiary explained by its trend is 85 percent, which is quite similar to that of real primary spending.

We now turn to the cyclical properties of social security spending. Figure 13 shows the cyclicality of social security spending. The correlation is -0.09 (and statistically barely significant) in industrial countries and 0.13 (and statistically significant) in the developing world (see also "social security" box in Figure 3). Moreover, and based on individual country correlations and statistical significance, we find, in line with these group findings, that (i) only 28 percent of industrial countries follow countercyclical policies (the rest exhibits an acyclical profile) and (ii) about 45 percent of developing economies follow procyclical policies (the rest show an acyclical profile).

\section{FIGURE 13}

Figure 14 shows that, in the industrial world, the barely countercyclical spending behavior observed in Figure 13 is mainly driven by the countercyclical profile of the number of beneficiaries in some countries (Panel A in Figure 14), as opposed to the behavior observed in the spending per beneficiary, which is virtually acyclical across the board (Panel B in Figure 14). Moreover, as discussed in World Bank (2009), "the number of [social security] beneficiaries typically increases during a crisis, as people look to early retirement and disability as a means to cope with unemployment." In fact, if one excluded the years 2009, 2010, and 2011 from the analysis, the number of beneficiaries would become acyclical (i.e., statistically not significant) in each industrial country but Japan. Interestingly, and in spite of having information about the number of social security beneficiaries for few developing countries, Figure 14 indicates that the procyclical spending behavior observed in Figure 13 in developing economies is mainly driven by the procyclical profile of spending

per beneficiary (Panel B in Figure 14), as opposed to the number of beneficiaries, which is acyclical (Panel A in Figure 14).

FIGURE 14

In sum - and in spite of the intrinsically structural/rigid nature of this entitlement program 
(especially regarding the number of beneficiaries which is driven by slowly-moving demographic considerations) - while the industrial world shows, by and large, an acyclical social security spending policy profile (i.e., social security systems work in practice as predicted by the theory), many developing countries show a procyclical social security spending behavior (essentially driven by fluctuations in individual social security benefit payments), which is at odds with the theoretical expectation.

\subsection{Relevance of formulas (or lack thereof) for social security procyclicality}

As will become clear in the remainder of this section, a key aspect affecting the cyclicality of social security spending in practice is whether adjustments over time of individual social security benefit payments depend upon fixed-formulas or, instead, rely more on ad-hoc/discretionary decisions by policymakers. ${ }^{14}$ As illustrated in Figure 15, by and large, industrial countries have historically adjusted individual social security benefit payments following automatic indexation mechanisms, typically linked to changes in cost of living like prices or wages, with the purpose of maintaining constant retirees' purchasing power over time (hereafter, we use the term automatic price-based formula indexation mechanism). ${ }^{15,16}$ On the other hand, as also shown in Figure 15, less than half of the developing world has followed automatic price-based formula indexation mechanisms and has instead relied on policymakers' ad-hoc/discretionary criteria to adjust individual social security benefit payments. Figure 16 shows, for the most up-to-date data, whether individual countries in the world rely on automatic price-based formula indexation mechanisms (red color) or not (white color).

\section{FIGURES 15 AND 16}

We now analyze whether formulas (or lack thereof) affect, from an empirical point on view, social security procyclicality. Figure 17 shows that having (or not) some automatic price-based formula indexation mechanism indeed matters for social security cyclicality. Panel A shows that when countries have automatic price-based formula indexation mechanisms, social security spending is acyclical; the correlation is 0.02 (and statistically not significant). Even for the developing world, the correlation is 0.06 (and not statistically significant); with no country showing procyclical

\footnotetext{
${ }^{14}$ This distinction is relevant to the prevalent pervasive pay-as-you-go social security system's funding method (OECD, 2019; Demarco, 2019; Holzmann et al., 2020) and, naturally, does not apply to pre-funded retirement programs (where the money is saved in advance so that it will be available to be paid out to today's workers when they retire). Therefore, the remainder of this section will exclude pre-funded retirement programs (or their component) from the analysis.

${ }^{15}$ While other criteria have been used for formula indexation mechanisms, including those based on revenues and GDP growth, these cases are quite uncommon, representing less than 5 percent of sample.

${ }^{16}$ The first automatic price-based formula indexation mechanism dates back to 1922 when Denmark amended its pension law by linking general pensions to changes in the salaries of government employees, with semiannual adjustments. This early provision was repealed in 1927, to be replaced in the Danish national insurance act of 1933 by automatic adjustments based on changes in the national price index. Based on the Danish initiative, Iceland and Luxembourg followed in 1946 and France in 1948, respectively (SSA, 1960).
} 
behavior. In contrast, Panel B shows that when countries do not have automatic price-based formula indexation mechanisms and rely instead on ad-hoc/discretionary criteria to adjust individual social security benefit payments, social security spending is procyclical (the correlation is 0.17 and statistically significant), with 63 percent of developing countries following procyclical social security spending.

\section{FIGURE 17}

Half of the countries are shown both in Panel A and in Panel B of Figure 17 because the available social security spending data covers both periods with automatic price-based formula indexation mechanisms and periods relying on ad-hoc/discretionary criteria. For example, during 1993-2003, the Slovak Republic resorted to ad-hoc/discretionary decisions by the parliament to adjust individual social security benefit payments. In 2003, the country approved the first phase of its pension reform, to be implemented in 2004, linking the annual adjustment of benefits to the changes in prices and in average nominal wages (SSA, 2003). ${ }^{17}$ Interestingly, and in line with our previous general findings, the social security spending cyclicality observed in the Slovak Republic when its social security system relied on ad-hoc/discretionary criteria was procyclical, while it was acyclical once the automatic price-based formula indexation mechanism was introduced (0.76 in Panel B versus -0.13 in Panel A). The Slovak Republic is far from being a special case: in all countries present both in Panel A and in Panel B of Figure 17, the cyclicality of social security spending illustrated in Panel B is larger than in Panel A.

Figure 18 conveys, in a different way, the same message based on a cross-sectional cut of the same underlying data: the lower the percentage of years a country relied on automatic price-based formula indexation (i.e., the more a country has relied on ad-hoc/discretionary decisions by policymakers), the more procyclical is social security spending.

\section{FIGURE 18}

In sum, when individual social security benefit payments are adjusted based on automatic pricebased formula indexation mechanisms, social security spending is acyclical. The reasons are twofold. First, a slowly-moving and intrinsically structural/rigid number of social security beneficiaries entitled to this program (independently of the nature of the adjustment mechanism, as it is driven by demographic considerations). Secondly, and more crucially, the automatic price-based formula indexation mechanism itself which, by design, aims to maintaining retirees' purchasing power (and thus the social security spending per beneficiary) constant over time. In other words, under au-

\footnotetext{
${ }^{17}$ This 2003 pension reform triggered a sequence of further pension reforms affecting the weights used for changes in prices and changes in average nominal wages. For the period 2004-2013, the weights were 50 percent due to price changes and 50 percent to changes in average nominal wages. These weights further changed in favor of changes in prices to 60 percent in 2014, 70 percent in 2015, 80 percent in 2016, 90 percent in 2017, and 100 percent in 2018 (ILO, 2017).
} 
tomatic price-based formula indexation mechanisms, social security spending works in practice as expected theoretically, with slow changes over time that are unrelated to the business cycle. In contrast, when individual social security benefit payments are adjusted based on ad-hoc/discretionary decisions by policymakers, social security spending is procyclical. ${ }^{18}$

\subsection{Why does lacking a formula make social security spending procyclical?}

In principle, the lack of a price-based formula indexation mechanism and reliance instead on policymakers' ad-hoc/discretionary decisions does not necessarily imply that social security spending will be procyclical (i.e., benefit payments increase in good times and fall in bad times).

Interestingly, in practice, countries relying on ad-hoc/discretionary decisions by policymakers for social security spending purposes tend to have (i) more sovereign defaults on external debt (Figure 19) and (ii) social security systems with lower net financial worth (Figure 20). These facts imply that countries relying on ad-hoc/discretionary decisions by policymakers for social security spending purposes have (vis-à-vis countries with automatic price-based formula indexation mechanisms) less readily available social security funds in the social security system coffers and no access to capital markets (or, alternatively, very high borrowing costs.

\section{FIGURES 19 AND 20}

The slow-moving and intrinsically structural/rigid nature of social security beneficiaries entitled to social security benefits coupled with more severe financial constraints observed in countries relying on ad-hoc/discretionary decisions by policymakers for social security spending purposes naturally increases the dependence of individual social security benefit payments adjustment over time to the availability of current social security revenues. Social security revenues comove positively, in a "mechanic" fashion, with economic activity because employment and income, which are the key underlying inputs behind social security revenues, track economic activity very closely. ${ }^{19}$ Therefore, the inability/difficulty to borrow and limited existence of readily available funds "force" social security spending to reflect the behavior of social security revenues (and consequently of economic activity). Naturally, this implies that social security spending will be, in practice, procyclical. In fact, Figure 21 shows that having (or not) some automatic price-based formula indexation mechanism indeed matters for the relationship between the cyclical components of social security spending

\footnotetext{
${ }^{18}$ Interestingly, in practice, when countries (either industrial or developing) rely on automatic price-based formula indexation mechanisms, the share of the variance of social security real spending explained by its trend reaches 95 percent. In contrast, when relying on policymakers' ad-hoc/discretionary criteria to adjust social security benefit payments, the share of the variance of social security real spending explained by its trend is 80 percent (and statistically lower than that of 95 percent observed when automatic price-based formula indexation mechanisms are present). In other words, automatic price-based formula indexation mechanisms do indeed provide, as one may have expected, more rigid spending than more ad-hoc/discretionary systems.

${ }^{19}$ These largely positive correlations across the board are also in line with Vegh and Vuletin (2015) when analyzing general government revenues. Results are not shown for brevity's sake.
} 
and revenues. Panel A shows that when countries have automatic price-based formula indexation mechanisms, social security spending is acyclical; the correlation is 0.12 (and statistically not significant). In contrast, Panel B shows that when countries do not have automatic price-based formula indexation mechanism and, instead, rely on ad-hoc/discretionary criteria to adjust individual social security benefit payments, social security spending and revenues comove positively (with a correlation of 0.37 , and statistically significant).

\section{FIGURE 21}

To sum up, while, in principle, adjustments of individual social security benefit payments based on ad-hoc/discretionary criteria do not necessarily imply procyclicality, in practice, the lack of an automatic price-based formula indexation mechanism reflects underlying borrowing constraints and the inability to save. This, in turn, makes social security spending procyclical because it ends up being determined by social security revenues (which are positively associated with economic activity). Common illustrations of social security procyclicality include ad-hoc/discretionary (i) increases in individual benefit payments during good times (e.g., increases of nominal individual benefit payments beyond inflation between 2003-2006 in Argentina), (ii) nominal pension cuts during bad times linked to fiscal adjustments (e.g., cuts to the highest pensions in 2012 in Greece), and (iii) nominal pension freeze in the context of moderate to high inflation (e.g., Argentina in 1976). In other words, the procyclicality of automatic spending observed in the developing world reflects the behavior of social security spending, in particular the reliance on ad-hoc/discretionary decisions by policymakers. This occurs, precisely, because the lack of commitment to a formula reflects underlying borrowing constraints and the inability to save.

\section{How important are automatic stabilizers (and de-stabilizers) in determining the degree of cyclicality of total spending?}

After focusing in previous sections on the cyclical behavior of the most important automatic spending categories, we now analyze the extent to which these aforementioned automatic stabilizers (or de-stabilizers) arguments actually matter in determining the degree of cyclicality of total spending (primary spending, to be precise). As will become clear below, even after controlling for other well-known determinants and addressing potential endogeneity concerns, unemployment insurance and automatic price-based formula indexation mechanisms are found to be important and robust determinants of the cyclicality of total spending.

Given the difficulty of finding time-varying instrumental variables for unemployment insurance and automatic price-based formula indexation mechanisms, we follow Lane (2003) and Frankel, 
Vegh, and Vuletin (2013) and rely on cross-country regressions. ${ }^{20}$ Table 1 shows the results of cross-country regressions where the dependent variable is the country correlation between the cyclical components of real primary spending and real GDP for the period 1980-2018 (i.e., the values from Figure 1). Explanatory variables (evaluated at the average for each country) include novel arguments such as the effective unemployment insurance mechanism coverage and the percentage of years without automatic price-based formula indexation mechanisms, discussed above in the text, as well as common determinants such as institutional quality, financial integration, and checks and balances. $^{21}$

To address potential endogeneity concerns, we use well-known instruments for institutional quality, financial integration, and checks and balances, and propose novel ones for effective unemployment insurance mechanism coverage and percentage of years without automatic price-based formula indexation mechanisms. We instrument institutional quality using the latitude (in absolute value) of the country's capital city (Acemoglu, Johnson, and Robinson, 2001), financial integration using legal origin (La Porta et al., 1997), and checks and balances using constraints on the executive and democracy in 1900 (La Porta et al., 1997). As an instrument for effective unemployment insurance mechanism coverage, and in light of our discussion in Section 3.1 and the evidence shown in Figure 10 where informality is typically identified as the main reason for the lack of unemployment insurance mechanisms, we propose using the share of agriculture in GDP circa 1950. This is because of the positive association between the size of the agricultural sector and informality (e.g., Saracoglu, 2008; Vuletin, 2008). Considering our discussion in Section 5.2 and evidence shown in Figure 19, we propose using the percentage of years with sovereign default on external debt during the period 1960-1975 as an instrument for the percentage of years without automatic price-based formula indexation mechanisms.

Panel A in Table 1 shows the results of cross-country regressions without using instruments. Columns 1 to 5 show our findings when using one determinant at a time. Column 1 shows that, indeed, larger effective unemployment insurance mechanism coverage is associated with less total spending procyclicality. Column 2 indicates that the lower the prevalence of automatic price-based formula indexation mechanisms, the higher the procyclicality. Columns 3 to 5 show, much like in the existing literature, that better institutions, more financial integration, and more checks and balances (all variables introduced one at a time) also lead to less total spending procyclicality. Column 6 includes all determinants, except for unemployment insurance mechanism coverage; column 7 includes all determinants, except for automatic price-based formula indexation mechanisms; and column 8 includes all determinants. All in all, the evidence indicates that these two new deter-

\footnotetext{
${ }^{20}$ Based on analogous considerations, for example, it is also standard in the literature on institutions to rely on cross-country regressions for instrumentation purposes (e.g., Acemoglu, Johnson and Robinson, 2001; Easterly and Levine, 2003; Glaeser, La Porta, Lopez-de-Silanes, and Shleifer, 2004; Rodrik, Subramanian, and Trebbi, 2004; La Porta, Lopez-de-Silanes and Shleifer, 2008).

${ }^{21}$ See Frankel, Vegh, and Vuletin (2013) for a more detailed discussion and Appendix 1 for definition of variables and sources of data.
} 
minants linked to automatic stabilizers (or de-stabilizers) are very important in determining the degree of cyclicality of total spending, even after controlling for other well-known determinants.

We now control for possible endogeneity using instrumental variables. Table 2 shows that the proposed instruments relate in the expected manner with all five cyclicality regressors. Panel B in Table 1 shows the cross-country regressions using instrumental variables. In all cases, we cannot reject the overidentification tests. The instruments are valid (i.e., uncorrelated with the error term) and the excluded instruments are correctly excluded from the estimated equation. Moreover, weak identification tests confirm that the excluded instruments are not weak instruments (i.e., they are strongly correlated with the endogenous regressors). As expected when using instrumental variables, the statistical significance of some regressors weakens. Yet, all in all, and despite the reduction in the number of countries, the relevance of the two newly identified determinants linked to automatic stabilizers (or de-stabilizers!) arguments remains very important in explaining the degree of cyclicality of total spending, even after controlling for other well-known factors and addressing potential endogeneity concerns.

\section{TABLES 1 AND 2}

To sum up, much like well-known determinants of cyclicality of spending policy such as institutional quality, financial integration, and checks and balances, these new findings support the idea that unemployment insurance and, more interestingly and subtly, the presence of social security automatic price-based formula indexation mechanisms are, indeed, important and robust determinants of the cyclicality of total government spending.

\section{Revisiting the merits of government spending as a macroeco- nomic stabilizer}

There is a general consensus in the literature that more government spending, especially automatic government spending, acts as a macroeconomic stabilizer (e.g., Gali, 1994; Fatas and Mihov, 2001, 2003; McKay and Reis, 2016). Panel A in Table 3 shows the results of cross-country regressions where the dependent variable is output volatility measured by the standard deviation of annual real GDP growth for the period 1980-2018. Column 1 shows that larger government spending reduces output volatility. Moreover, column 2 shows that such stabilizing force is mainly driven by its automatic spending component as opposed to the discretionary one. These findings are well in line with the existing literature such as Fatas and Mihov (2001 and 2003) in that what truly matters for macroeconomic stabilization is the size of automatic government spending.

We now revisit these findings through the lenses of the new insights of our paper. Columns 3 to 5 condition the impact of automatic government spending on the presence of unemployment insurance and social security formula-based indexation mechanisms. Columns 3 to 5 keep showing 
the irrelevance of discretionary spending size on output volatility. However, more interestingly, it also shows (in line with our previous findings) that not all automatic government spending is alike in terms of its stabilizing properties. Only when more automatic government spending is conducted in the presence of unemployment insurance and social security formula-based indexation mechanisms, does it act as a stabilizing force. While the importance of unemployment insurance in this regard is well known by now (e.g., McKay and Reis, 2016; Di Maggio and Kermani, 2016; Krueger, Mitman, Perri, 2016), the practical relevance of having a social security formula-based indexation mechanism has not, to the best of our knowledge, been previously identified. Columns 6 to 10 in Panel A in Table 3 are equivalent to columns 1 to 5 , yet also control for a well-known determinant of output volatility: terms of trade volatility. Our previous findings remain unchanged.

Panel B in Table 3 is equivalent to Panel A, yet uses instrumental variables to address endogeneity concerns. Following the strategy of the existing fiscal literature, we instrument the size of government spending (primary spending, to be precise) using the nature of the political system: presidential versus parliamentary. Persson and Tabellini (1999) argue that the direct accountability of politicians in presidential systems increases the competition both among politicians and voters and this implies less spending on every budget item and smaller governments. Panel A in Table 4 empirically supports this argument (i.e., that presidential systems induce less government spending). To account for the share of government spending allocated to discretionary and automatic spending, we use the old-age dependency ratio (defined as the ratio of people older than 64 to the working-age population aged 15 to 64 ). Several studies have found that a higher old-age dependency ratio increases spending, especially social security for the population over 65 (e.g., Sanz and Velazquez, 2007; Sorensen, 2013). In fact, Panel B in Table 4 empirically supports the argument that a higher old-age dependency ratio is associated with a larger share of automatic government spending. Naturally, to instrument for discretionary and automatic spending, one also needs to interact the political system variable with this demographic-based one. We also address endogeneity concerns about the recent presence of unemployment insurance and social security formula-based indexation mechanisms for the period 1980-2018 by using their presence circa 1970 and at the beginning of each country's sample, respectively (see panels C and D in Table 4 4). When using this set of instruments, we naturally use all required interactions. Panel B in Table 3 shows that even after addressing endogeneity considerations, the main findings remain unchanged. Naturally in all cases, the coefficients observed in Panel A in Table 3 (without using instruments) tend to be more significant than in Panel B in Table 3 (using instruments).

\section{TABLES 3 AND 4}

To sum up, unemployment insurance and, more interestingly and subtly, the presence of social security automatic price-based formula indexation mechanisms are, indeed, important and robust 
factors affecting the influence of automatic government spending on macroeconomic volatility. In other words, automatic government spending per se is not sufficient to reduce macroeconomic instability, as the presence of transfer programs, such as unemployment insurance and social security, prove to be essential.

\section{Final thoughts}

We have shown that while automatic government spending is (as expected) countercyclical in industrial countries, it is surprisingly procyclical in the developing world. We track this puzzling procyclical behavior to (i) the effective lack of automatic stabilizers like unemployment insurance and (ii) more intriguing, to the existence of perverse automatic de-stabilizing mechanisms in social security spending (especially when lacking formula indexation mechanisms). We also show that the presence and nature of these two social programs are crucial new determinants of countries' government spending cyclicality as well as macroeconomic volatility. These new insights, particularly that of the critical relevance of social security formula indexation mechanisms, and its possible de-stabilizing effect when such formulas tend not to be present, is of great concern considering the current size of social security spending (about 80 percent of automatic government spending and 40 percent of primary government spending) and its expected persistent growth (could grow between 2 and 5 -fold in the next 40 years).

\section{References}

Acemoglu, D., Johnson, S., Robinson, J.A., 2001. The colonial origins of comparative development: An empirical investigation. American Economic Review 91 (5), 1369-1401.

Aleksynska, M., Schindler, M., 2011. Labor market regulations in low-, middle- and high-income countries: A new panel database. IMF Working Paper No. 11/154.

Alesina, A., Campante, F., Tabellini, G., 2008. Why is fiscal policy often procyclical? Journal of the European Economic Association 6 (5), 1006-1036.

Alvarez-Parra, F., Sanchez, J.M., 2009. Unemployment insurance with a hidden labor market. Journal of Monetary Economics 56 (7), 954-967.

Ardanaz, M., Izquierdo, A., 2017. Current expenditure upswings in good times and capital expenditure downswings in bad times? New evidence from developing countries. IDB Working Paper No. 838.

Asenjo, A., Pignatti, C., 2019. Unemployment insurance schemes around the world: Evidence and policy options. ILO Research Department Working Paper No. 49.

Avellan, L., Vuletin, G., 2015. Fiscal procyclicality and output forecast errors. Journal of International Money and Finance 55, 193-204.

Bianchi, J., Ottonello, P., Presno, I., 2019. Fiscal stimulus under sovereign risk. NBER Working Paper No. 26307.

Blanchard, O., 2006. Comments on "The case against the case against discretionary fiscal policy", in R.W. Kopcke, G.M.B. Tootell, and R. Triest (eds.), The macroeconomics of fiscal policy. Cambridge, MA: MIT Press, 62-67. 
Blanchard, O., Dell'Ariccia, G., Mauro, P., 2010. Rethinking macroeconomic policy. Journal of Money, Credit and Banking 42 (S1), 199-215.

Bongaarts, J., 2004. Population aging and the rising cost of public pensions. Population and Development Review, 30 (1), 1-23.

Bosch, M., Esteban-Pretel, J., 2015. The labor market effects of introducing unemployment benefits in an economy with high informality. European Economic Review 75 (C), 1-17.

Brown-Collier, E.K., Collier, B.E., 1995. What Keynes really said about deficit spending. Journal of Post Keynesian Economics 17 (3), 341-355.

Camarena, J.A., Galeano, L., Morano, L., Puig, J., Riera-Crichton, D., Vegh, C., Venturi, L., Vuletin, G., 2019. Fooled by the cycle: Permanent versus cyclical improvements in social indicators. NBER Working Paper No. 26199.

Cerutti, P., Fruttero, A., Grosh, M., Kostenbaum, S., Oliveri, M.L., Rodriguez-Alas, C., Strokova, V., 2014. Social assistance and labor market programs in Latin America: Methodology and key findings from the social protection database. Social Protection \& Labor Discussion Paper No. 1401.

Cespedes, L., Velasco, A., 2014. Was this time different? Fiscal policy in commodity republics. Journal of Development Economics 106, 92-106.

Chomik, R., Piggott, J., Yan, S., 2019. Aging, fiscal sustainability and adequacy of social security systems. Think 20 Policy Brief No. 12, Task Force 10.

Cuadra, G., Sanchez, J.M., Sapriza, H., 2010. Fiscal policy and default risk in emerging markets. Review of Economic Dynamics 13 (2), 452-469.

Demarco, G., 2019. Global pension policies: Past and present. Social Protection and Jobs 2019 Core Courses. The World Bank, Washington, DC.

Di Maggio, M.D., Kermani, A., 2016. The importance of unemployment insurance as an automatic stabilizer. NBER Working Paper No. 22625.

Duval, R.A., Loungani, P., 2019. Designing labor market institutions in emerging and developing economies: Evidence and policy options. IMF Staff Discussion Note No. 19/04.

Easterly, W., Levine, R., 2003. Tropics, germs, and crops: How endowments influence economic development. Journal of Monetary Economics 50 (1), 3-39.

Eckardt, S., Mills, Z., 2014. What goes up must come down: cyclicality in public wage bill spending. Policy Research Working Paper No. 6760.

Fatas, A., Mihov, I., 2001. Government size and automatic stabilizers: International and intranational evidence. Journal of International Economics 55 (1), 3-28.

Fatas, A., Mihov, I., 2003. The case for restricting fiscal policy discretion. The Quarterly Journal of Economics 118 (4), 1419-1447.

Fatas, A., Mihov, I., 2012. Fiscal policy as a stabilization tool. The BE Journal of Macroeconomics $12(3)$.

Fichtner, J., 2018. Global aging and public finance. Business Economics 53, 72-78.

Frankel, J., 2011. Over-optimism in forecasts by official budget agencies and its implications. Oxford Review of Economic Policy 27 (4), 536-562.

Frankel, J., Vegh, C.A, Vuletin, G., 2013. On graduation from fiscal procyclicality. Journal of Development Economics 100 (1), 32-47.

Freeman, R., 1987. How do public sector wages and employment respond to economic conditions? in David Wise (ed.), Public sector payrolls. University of Chicago Press, 183-216.

Gali, J., 1994. Government size and macroeconomic stability. European Economic Review 38 (1), 117-132.

Gavin, M., Perotti, R., 1997. Fiscal policy in Latin America. NBER Macroeconomics Annual 12, 11-61. 
Glaeser, E.L., La Porta, R., Lopez-de-Silanes, F., Shleifer, A., 2004. Do institutions cause growth? Journal of Economic Growth 9 (3), 271-303.

Gonzalez-Rozada, M., Ruffo, H., 2016. Optimal unemployment benefits in the presence of informal labor markets. Labour Economics 41(C), 204-227.

Holzmann, R., Palmer, E., Palacios, R., Sacchi, S., 2020. Progress and challenges of nonfinancial defined contribution pension schemes, Volume 1: Addressing marginalization, polarization, and the labor market. The World Bank, Washington, DC.

Hopenhayn, H.A., Nicolini, J.P., 1997. Optimal unemployment insurance. Journal of Political Economy 105 (2), 412-438.

International Labour Office, 2017. World social protection report 2017-19: Universal social protection to achieve the sustainable development goals. International Labour Office, Geneva.

Ilzetzki, E., Vegh, C., 2008. Procyclical fiscal policy in developing countries: Truth or fiction? NBER Working Paper No. 14191.

Izquierdo, A., Pessino, C., Vuletin, G., 2018. Better spending for better lives: How Latin America and the Caribbean can do more with less. DIA (Development in the Americas) Flagship, Inter-American Development Bank, Washington, DC.

Kaminsky, G., Reinhart, C., Vegh, C., 2004. When it rains, it pours: Procyclical capital flows and macroeconomic policies. NBER Macroeconomics Annual 19, 11-82.

Kraay, A., Van Rijckeghem, C., 1995. Employment and wages in the public sector: A crosscountry study. IMF Working Paper 70.

Krueger, D., Mitman, K., Perri, F., 2016. On the distribution of the welfare losses of large recessions. NBER Working Paper No. 22458.

La Porta, R., Lopez-de-Silanes, F., Shleifer, A., 2008. The economic consequences of legal origins. Journal of Economic Literature 46 (2), 285-332.

La Porta, R., Lopez-de-Silanes, F., Shleifer, A., Vishny, R.W., 1997. Legal determinants of external finance. Journal of Finance 52 (3), 1131-1150.

Lane, P.R., 2003. The cyclical behaviour of fiscal policy: Evidence from the OECD. Journal of Public Economics 87, 2661-2675.

Loayza, N.V., Ranciere, R., Servén, L., Ventura, J., 2007. Macroeconomic volatility and welfare in developing countries: an introduction. The World Bank Economic Review 21 (3), 343-357.

McKay, A., Reis, R., 2016. The role of automatic stabilizers in the US business cycle. Econometrica 84 (1), 141-194.

Medina, L., Schneider, F., 2018. Shadow economies around the world: What did we learn over the last 20 years? IMF Working Paper No. 18/17.

Michaud, A., Rothert, J., 2018. Redistributive fiscal policies and business cycles in emerging economies. Journal of International Economics 112 (C), 123-133.

Nerlich, C.,Schroth, J., 2018. The economic impact of population ageing and pension reforms. Economic Bulletin Articles, European Central Bank, Vol. 2.

OECD, 2019. Pensions at a glance 2019: OECD and G20 indicators. OECD Publishing, Paris.

Panadeiros, M., Pessino, C., 2018. Consecuencias fiscales del envejecimiento poblacional: proyecciones agregadas del gasto en salud para 10 países de América Latina. IDB Discussion Document No. 601.

Persson, T., Tabellini, G., 1999. The size and scope of government: Comparative politics with rational politicians. European Economic Review 43 (4-6), 699-735.

Riascos, A., Vegh, C., 2003. Procyclical government spending in developing countries: The role of capital market imperfections. Mimeo, UCLA and Banco República, Colombia.

Ribe, H.G., Robalino, D.A., Walker, D.I., 2012. From right to reality: Incentives, labor markets, and the challenge of universal social protection in Latin America and the Caribbean. Latin American 
Development Forum, World Bank Group, Washington, DC.

Rodrik, D., Trebbi, F., Subramanian, A., 2004. Institutions rule: The primacy of institutions over integration and geography in economic development. Journal of Economic Growth 9 (2), 131-165.

Sanz, I., Velazquez, F., 2007. The role of ageing in the growth of government and social welfare spending in the OECD. European Journal of Political Economy 23, 917-931.

Saracoglu, D.S., 2008. The informal sector and tax on employment: A dynamic general equilibrium investigation. Journal of Economic Dynamics and Control 32 (2), 529-549.

Social Security Administration, 1960. Automatic cost-of-living adjustment of pensions in foreign countries. Social Security Bulletin, US Social Security Administration, Woodlawn, Maryland.

Social Security Administration, 2003. International update: Recent developments in foreign public and private pensions. SSA Publication No. 13-11712. Office of Policy, US Social Security Administration, Washington, DC.

Sorensen, R., 2013. Does aging affect preferences for welfare spending? A study of peoples' spending preferences in 22 countries, 1985-2006. European Journal of Political Economy 29, 259271.

Spilimbergo, A., Symansky, S., Blanchard, O., Cottarelli, C., 2010 Fiscal policy for the crisis, in R. W. Kolb (ed.), Lessons from the financial crisis. New York: Wiley, 587-594.

Talvi, E., Vegh, C., 2005. Tax base variability and procyclicality of fiscal policy. Journal of Development Economics 78 (1), 156-190.

Tornell, A., Lane, P.R., 1999. The voracity effect. American Economic Review 89 (1), 22-46.

Uribe, M., Yue, V.Z., 2006. Country spreads and emerging countries: Who drives whom? Journal of international Economics 69 (1), 6-36.

Vegh, C, Vuletin, G., 2014a. Social implications of fiscal policy responses during crises. NBER Working Paper No. 20675.

Vegh, C, Vuletin, G., 2014b. The road to redemption: Policy response to crises in Latin America. IMF Economic Review 62, 526-568.

Vegh, C, Vuletin, G., 2015. How is tax policy conducted over the business cycle? American Economic Journal: Economic Policy 7, 327-370.

Vuletin, G., 2008. Measuring the informal economy in Latin America and the Caribbean. Money Affairs 21, 161-191.

Woo, J., 2009. Why do more polarized countries run more pro-cyclical fiscal policy? Review of Economics and Statistics 91 (4), 850-870.

World Bank, 2009. Pensions in crisis: Europe and Central Asia regional policy note. World Bank, Washington, DC. 
Figure 1. Country correlations between the cyclical components of real primary spending and real GDP

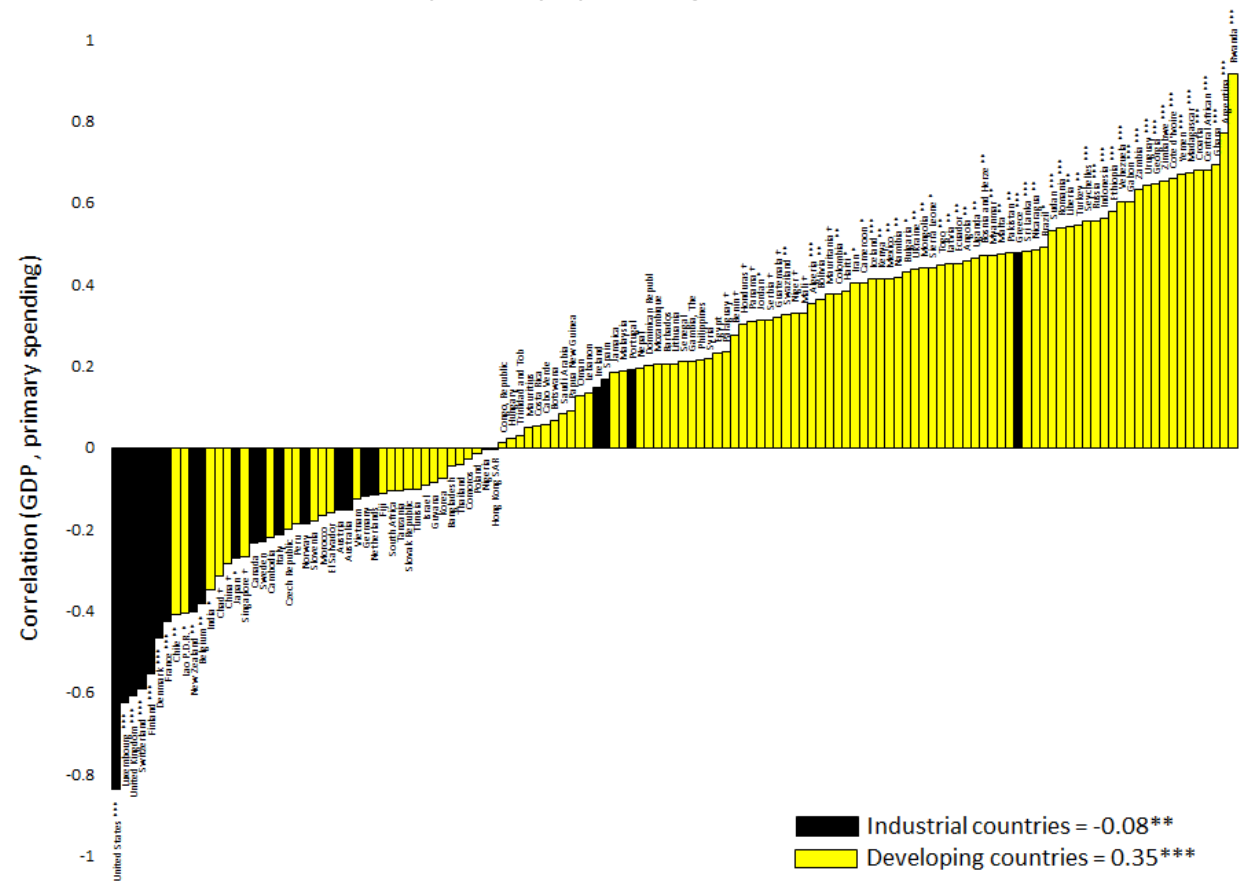

\begin{abstract}
Notes: Black (yellow) bars denote industrial (developing) countries. The cyclical components have been estimated using the Hodrick-Prescott filter. A positive (negative) correlation indicates procyclical (countercyclical) spending policy. Correlations refer to pooled across countries correlations. Real primary spending is defined as general government total expenditure net of interest payments, deflated by the GDP deflator. See Appendix 2 for correlation values for each country. $+, *, * *$ and ${ }^{* * *}$ indicate statistical significance at the $15 \%, 10 \%, 5 \%$ and $1 \%$ levels, respectively.

Sources: Authors' calculations based on World Economic Outlook and International Financial Statistics (IMF). See Appendix 1 for details. 131 countries for period $1980-2018$.
\end{abstract}

Figure 2. Correlations between the cyclical components of real primary spending (and its main categories) and real GDP in industrial (in italic font) and developing (in normal font) countries

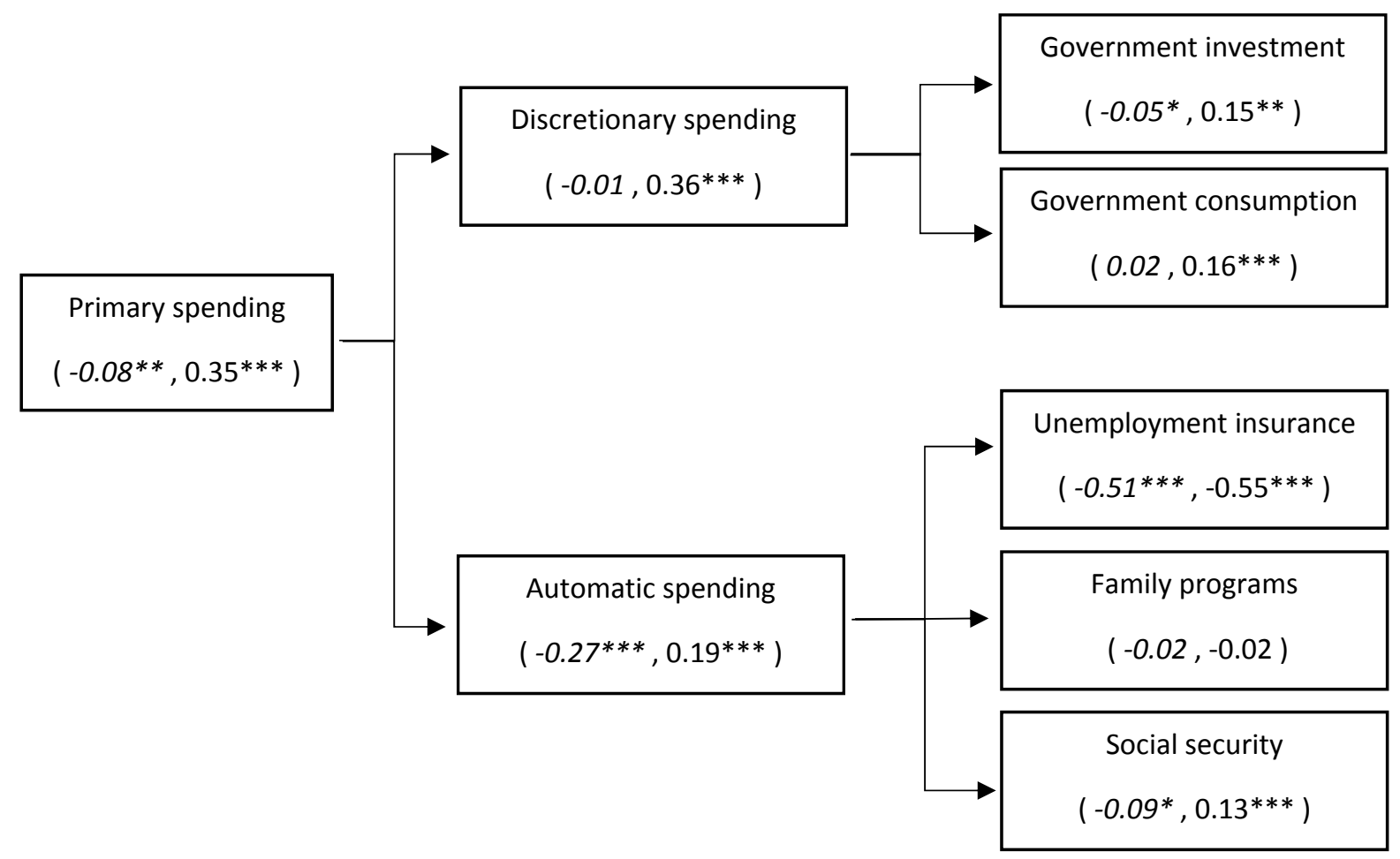

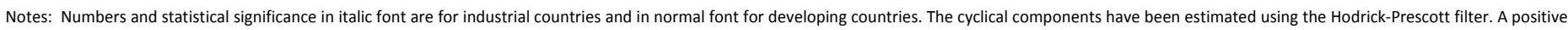

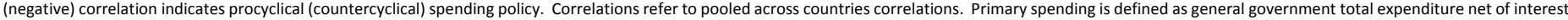

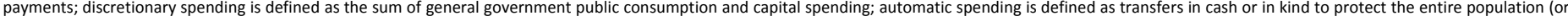

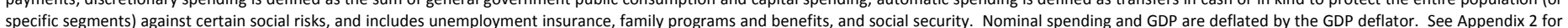
correlation values for each country. $+, *, * *$ and $* * *$ indicate statistical significance at the $15 \%, 10 \%, 5 \%$ and $1 \%$ levels, respectively.

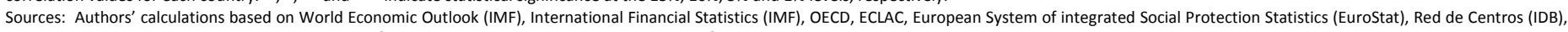
and national sources. See Appendices 1, 3, 4, and 5 for details. 131 countries using available data for the period 1980-2018. 
Figure 3. Importance of spending categories (as percentage of primary spending) in Industrial (in italic font) and developing (in normal font) countries

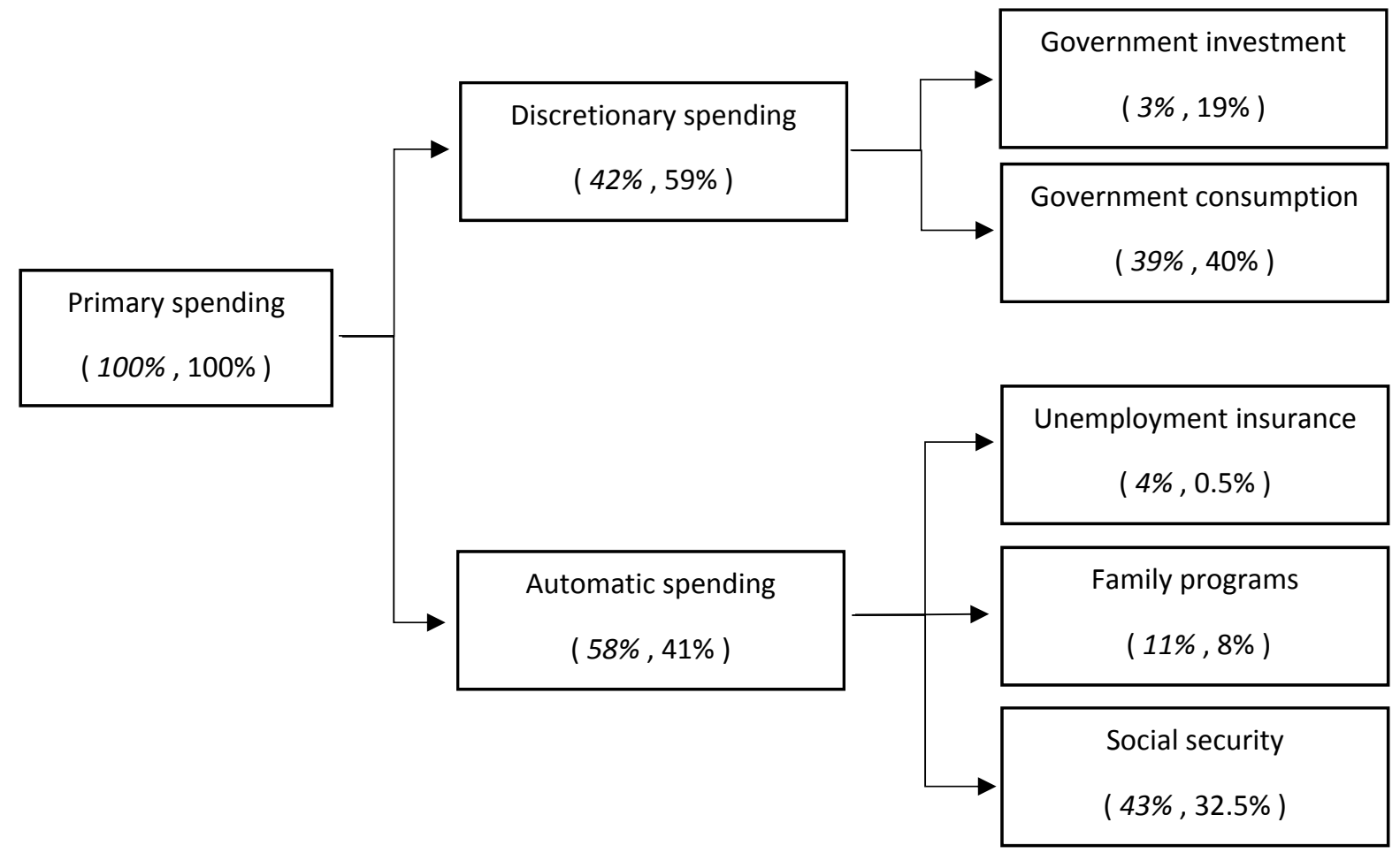

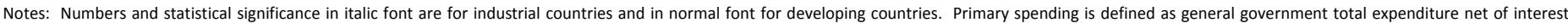

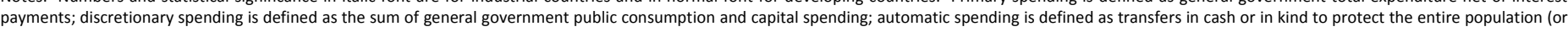
specific segments) against certain social risks, and includes unemployment insurance, family programs and benefits, and social security. Nominal spending and GDP are deflated by the GDP deflator.

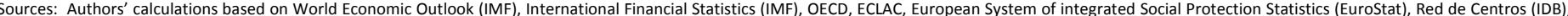
and national sources. See Appendices 1, 3, 4, and 5 for details. 131 countries using available data for the period 1980-2018.

Figure 4. Country correlations between the cyclical components of real discretionary spending and real GDP

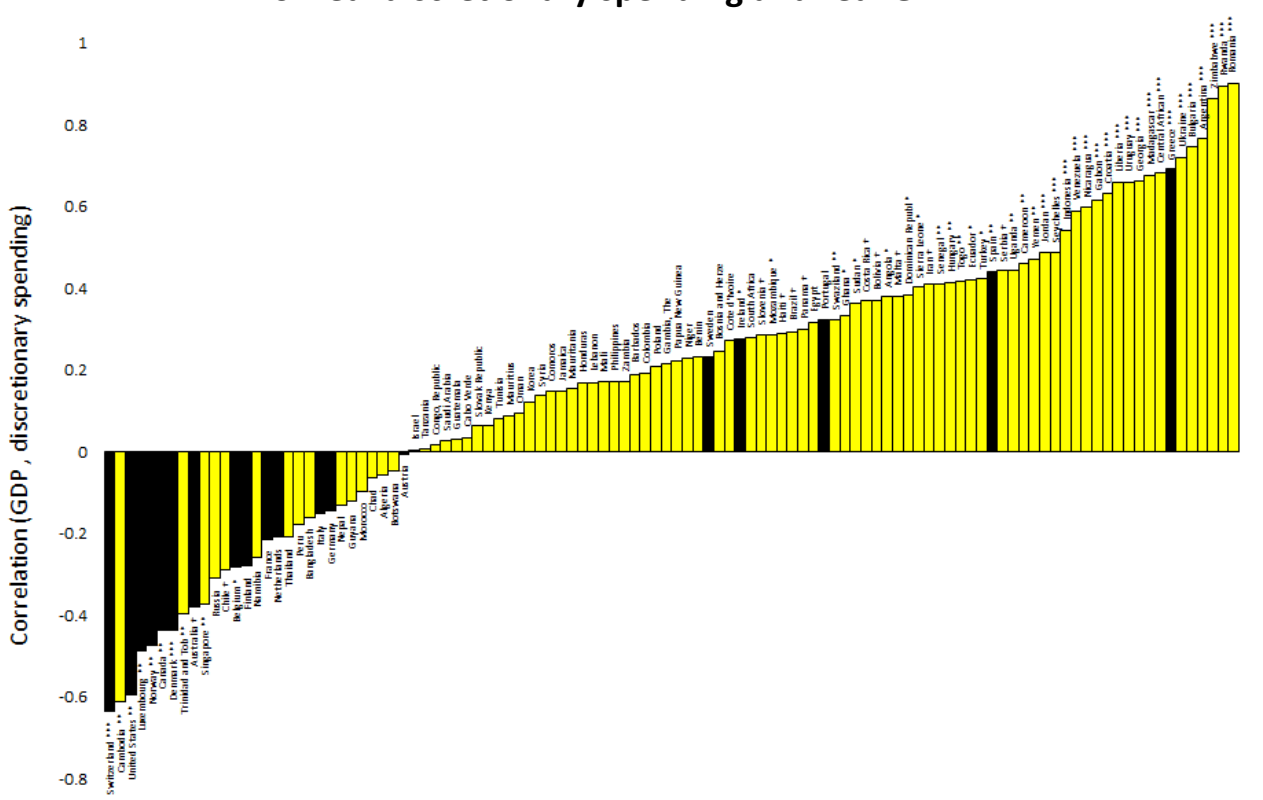

$\begin{array}{cl}\text {-1 } & \text { Industrial countries }=-0.01 \\ \text { Developing countries }=0.36^{* * *}\end{array}$

Notes: Black (yellow) bars denote industrial (developing) countries. The cyclical components have been estimated using the Hodrick-Prescott filter. A positive (negative) correlation indicates procyclical (countercyclical) discretionary spending policy. Correlations refer to pooled across countries correlation. Real discretionary spending is defined as the sum of general government public consumption and capital spending deflated by the GDP deflator. See Appendix 2 for correlation values for each country. $\dagger, *, * *$ and $* * *$ indicate statistical significance at the $15 \%, 10 \%, 5 \%$ and $1 \%$ levels, respectively. 
Figure 5. Country correlations between the cyclical components of real automatic spending and real GDP

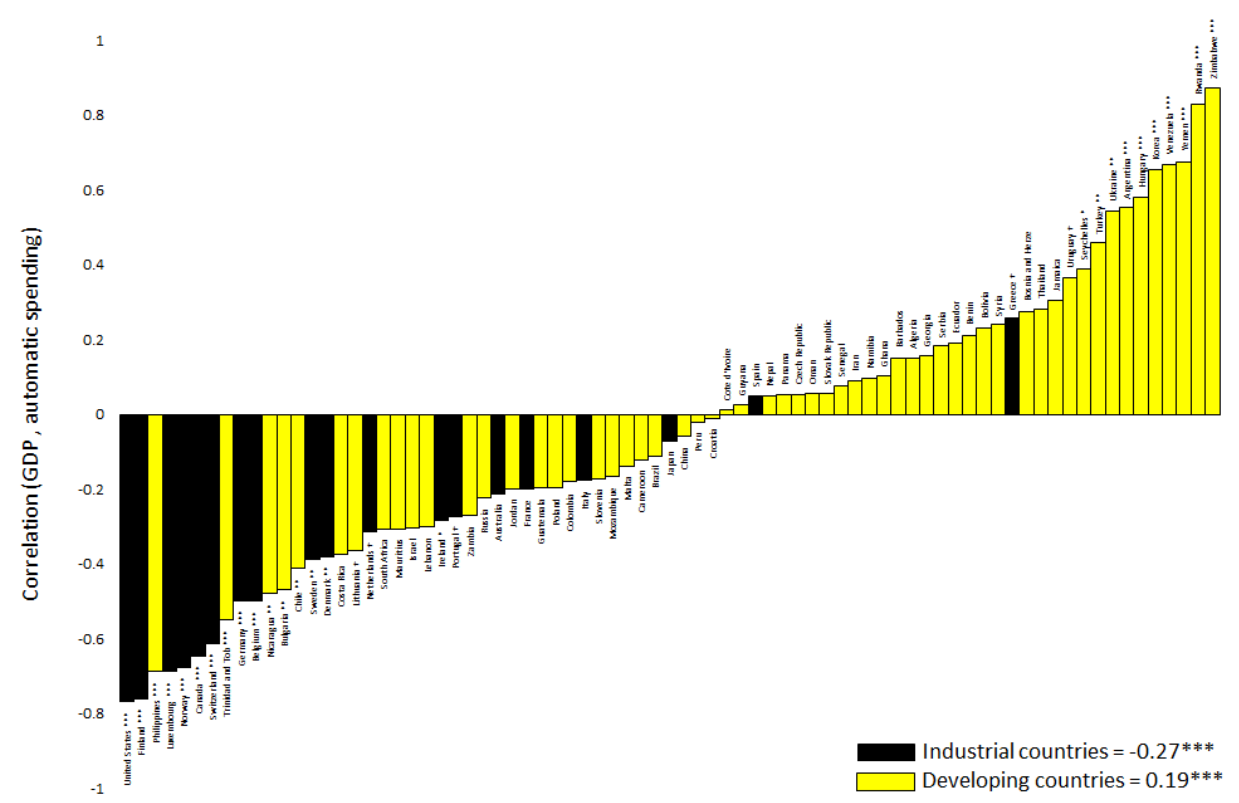

Notes: Black (yellow) bars denote industrial (developing) countries. The cyclical components have been estimated using the Hodrick-Prescott filter. A positive (negative) correlation indicates procyclical (countercyclical) automatic spending policy. Correlations refer to pooled across countries correlations. Real automatic spending is defined as transfers in cash or in kind to protect the entire population (or specific segments) against certain social risks, deflated by the GDP deflator. These transfers are classified according to the type of arrangement governing their payment, and consist of social security, family programs and benefits, and unemployment insurance. See Appendix 2 for correlation values for each country. $+, *, * *$ and $* * *$ indicate statistical significance at the $15 \%, 10 \%, 5 \%$ and $1 \%$ levels, respectively.

Sources: Authors' calculations based on World Economic Outlook and International Financial Statistics (IMF). See Appendix 1 for details. 77 countries for period $1980-2018$.

Figure 6. Country correlations between the cyclical components of real GDP and real unemployment insurance spending

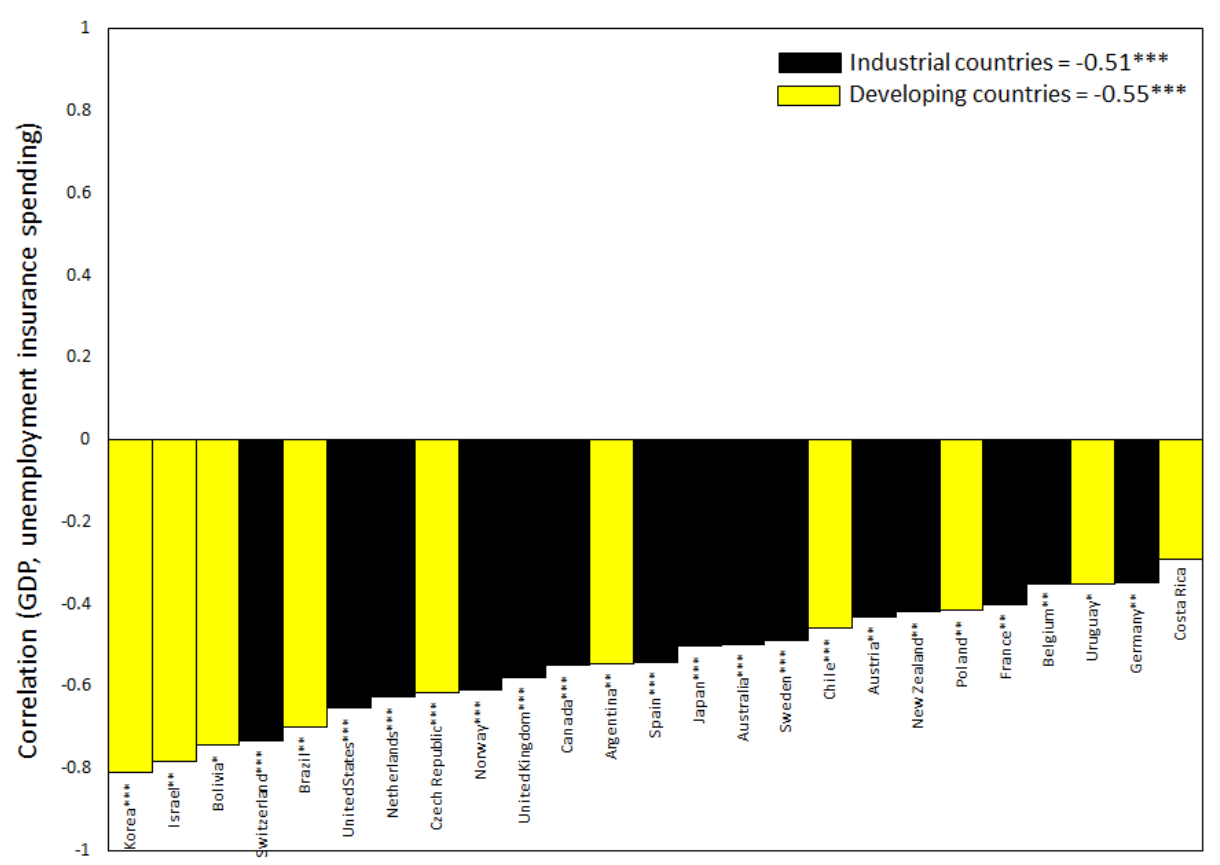

Notes: Black (yellow) bars denote industrial (developing) countries. The cyclical components have been estimated using the Hodrick-Prescott filter. A positive (negative) correlation indicates procyclical (countercyclical) unemployment insurance spending. Correlations refer to pooled across countries correlations. Real unemployment insurance spending is defined as unemployment insurance spending, deflated by the GDP deflator. See Appendix 2 for correlation values for each country. $+, *, * *$ and $* * *$ indicate statistical significance at the $15 \%, 10 \%, 5 \%$ and $1 \%$ levels, respectively.

Source: Authors' calculations based on Red de Centros (IDB) for Argentina, Bolivia, Brazil, Costa Rica, and Uruguay, and OECD for the rest of countries. See Appendix 3 for details. 25 countries for period 1980-2015. 
Figure 7. Country correlations between the cyclical components of real GDP and unemployment insurance beneficiaries (Panel $A$ ), and average real spending per beneficiary (Panel B)

Panel A. Cyclicality of unemployment insurance beneficiaries

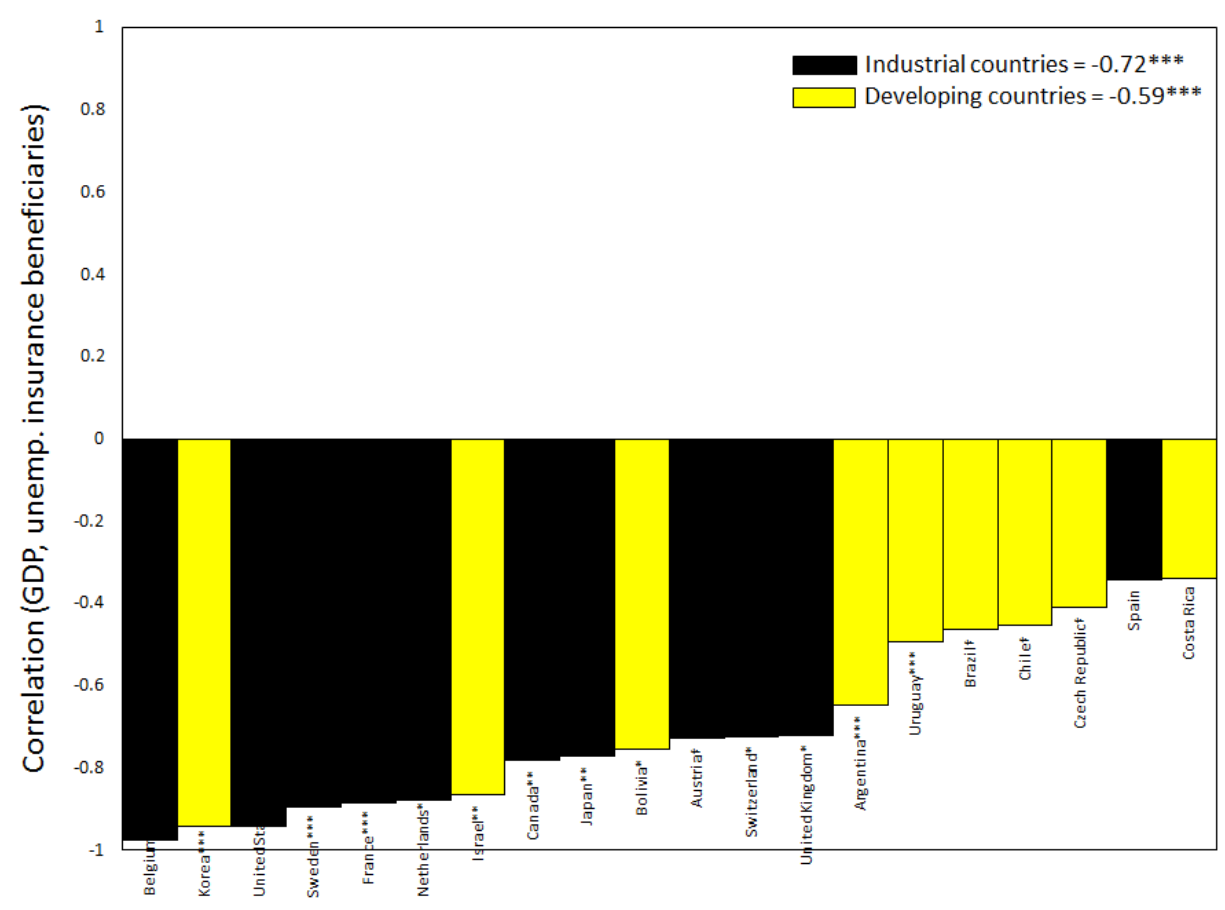

Panel B. Cyclicality of unemployment insurance average real spending per beneficiary

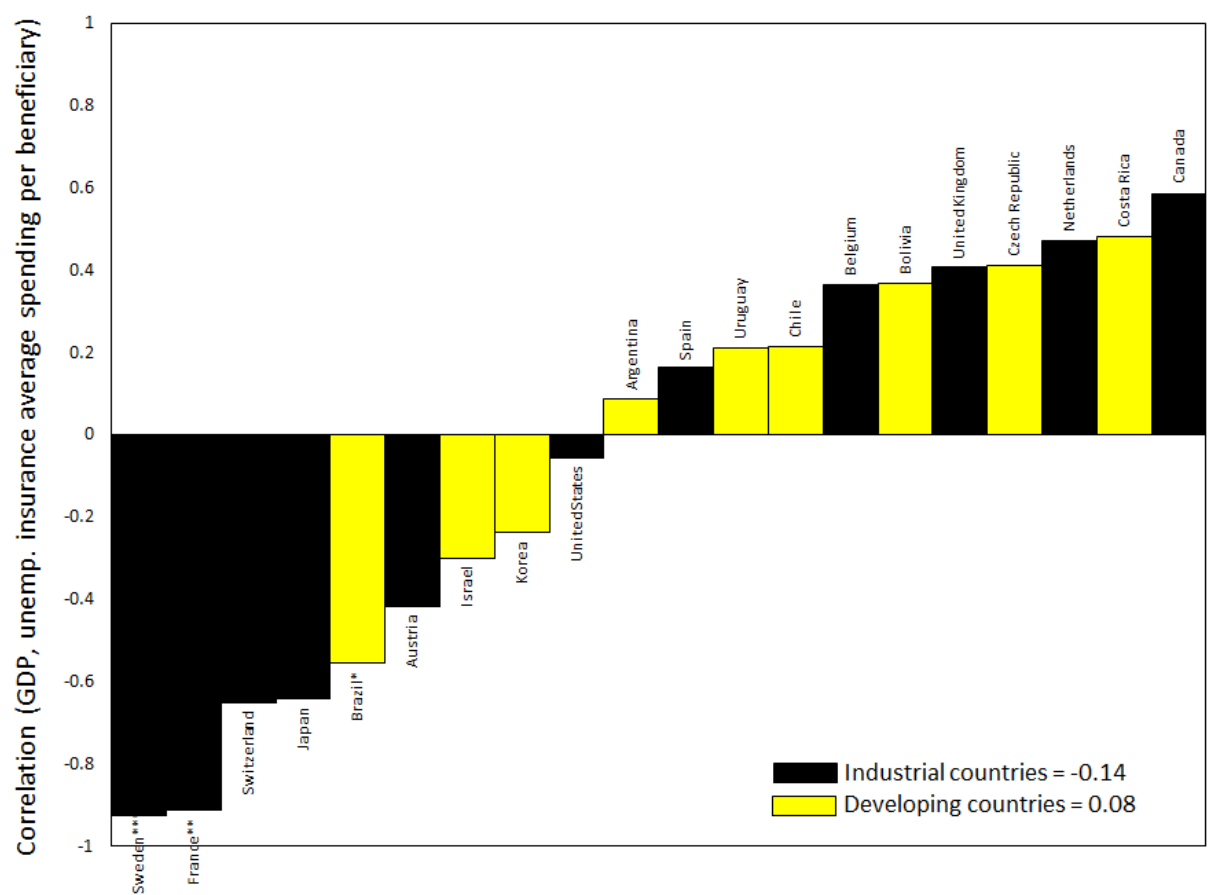

Notes: Black (yellow) bars denote industrial (developing) countries. The cyclical components have been estimated using the Hodrick-Prescott filter. A positive (negative) correlation indicates that unemployment insurance beneficiaries in Panel A, or unemployment insurance average spending per beneficiary in Panel B, commoves positively (or negatively) with the business cycle. Industrial and developing countries correlations refer to pooled across countries correlation. $+, *, * *$ and ${ }^{* * *}$ indicate statistical significance at the $15 \%, 10 \%, 5 \%$ and $1 \%$ levels, respectively.

Sources: Authors' calculations based on Red de Centros (IDB) for Argentina, Bolivia, Brazil, Costa Rica, and Uruguay, and OECD for the rest of countries. See Appendix 3 for details. 20 countries for period $1980-2015$ 
Figure 8. Presence of unemployment insurance mechanisms in the world circa 2019

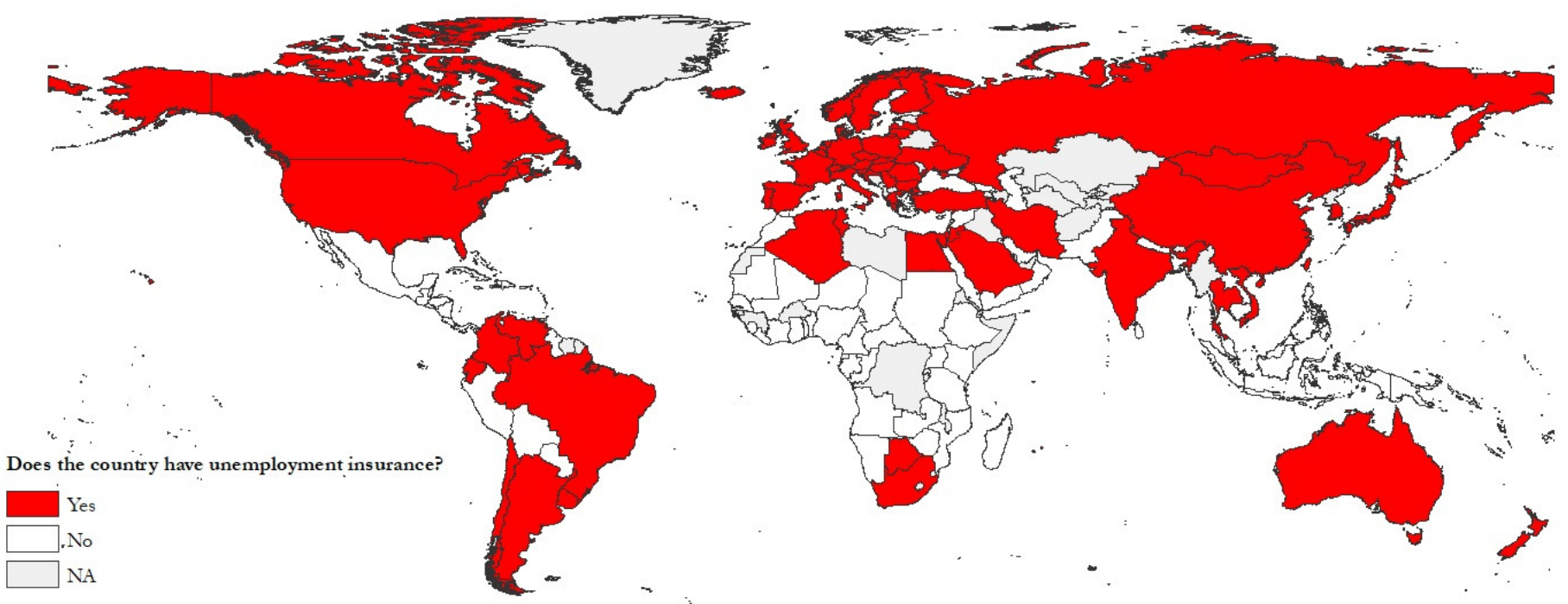

Notes: Countries in white do not have unemployment insurance mechanisms. Countries in red have some type of unemployment insurance mechanism.

Sources: Authors' identification based on International Labor Organization and United States Social Security Administration. See Appendix 3 for details.

Figure 9. Effective unemployment insurance mechanism coverage

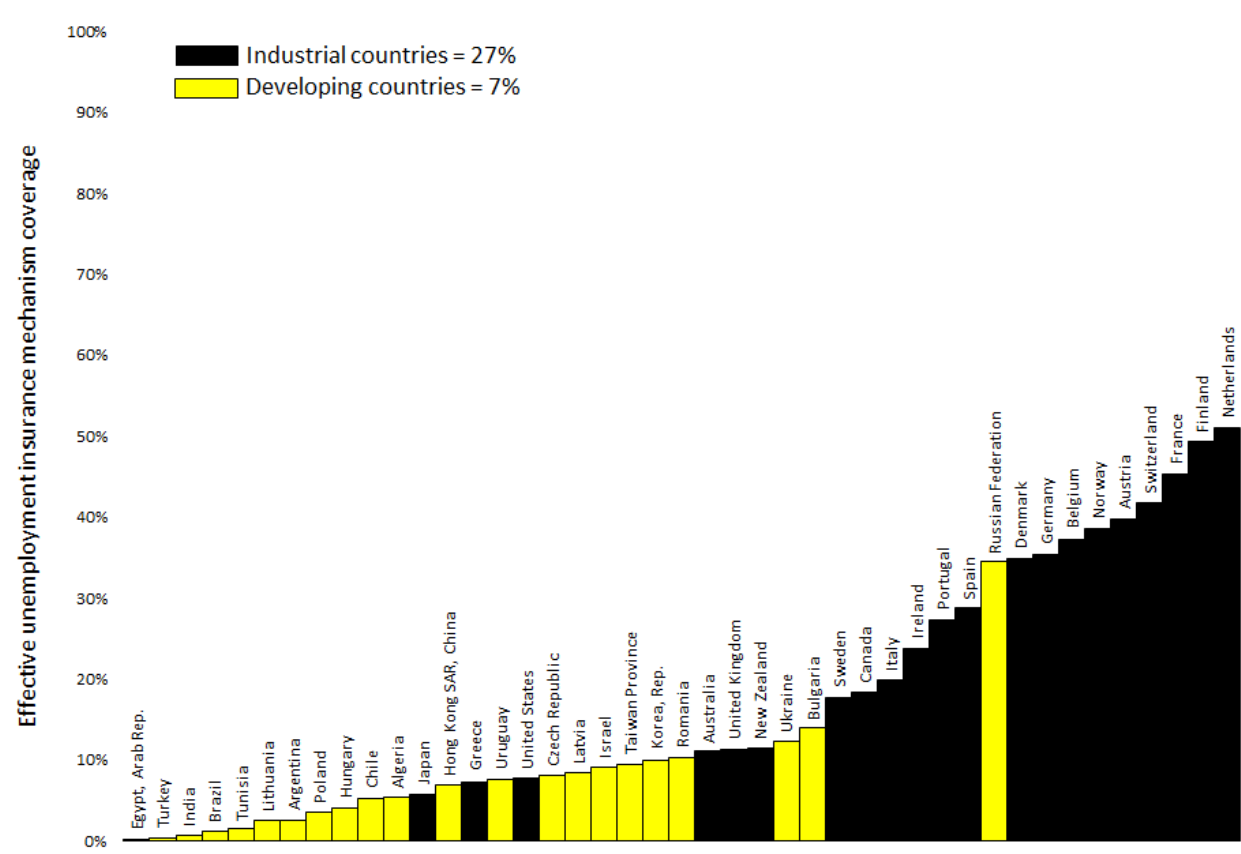

Notes: Black (yellow) bars denote industrial (developing) countries. Out of the 65 countries with some unemployment insurance mechanism, the authors found information on the effective unemployment insurance mechanism coverage for 43 countries.

Sources: Authors' calculations based on International Labor Organization and Aleksynska and Schindler (2011) circa 2010. See Appendix 3 for each country details. 
Figure 10. Relationship between effective unemployment insurance coverage and informality

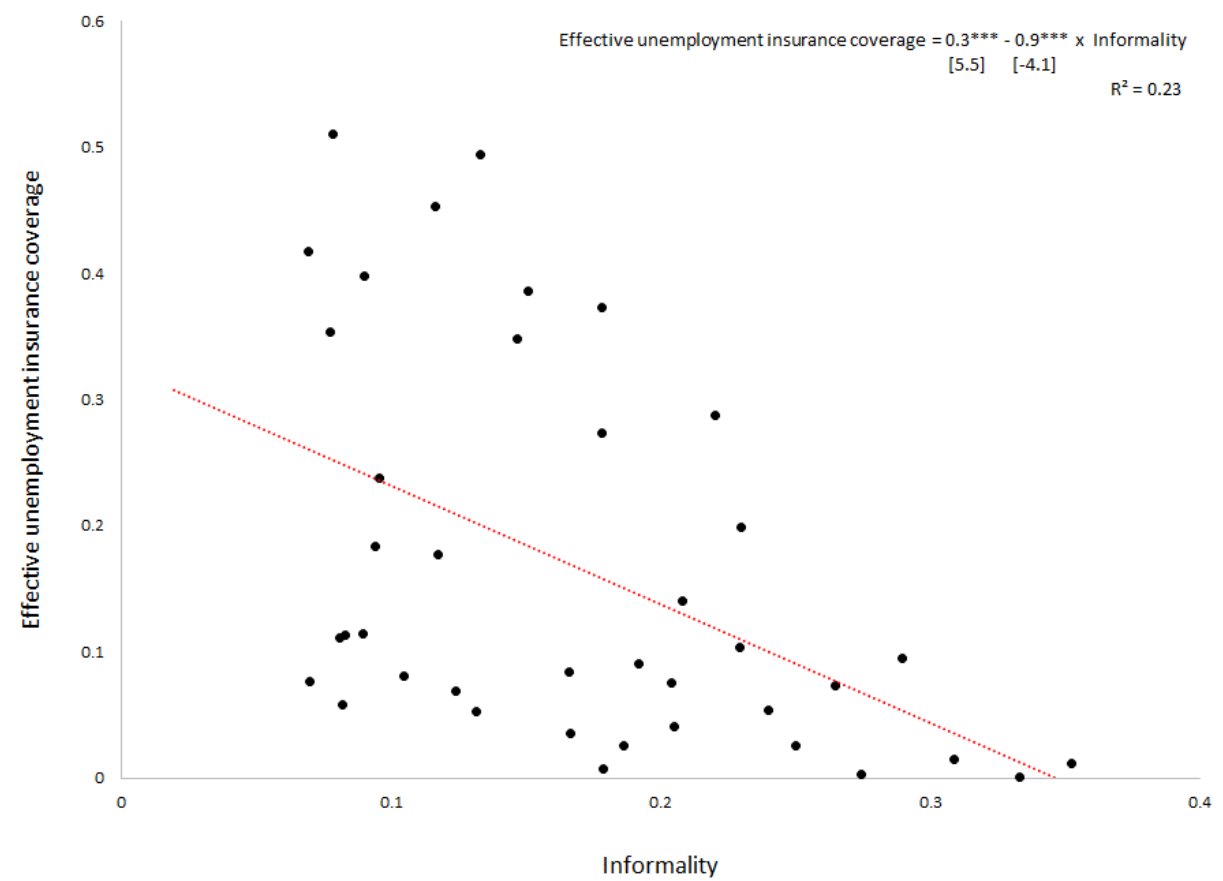

Sources: Effective unemployment insurance coverage computed by the authors based on International Labor Organization and Aleksynska and Schindler (2011) circa 2010. Informality is taken from Medina and Schneider (2018) circa 2010. Countries with no unemployment insurance mechanism are not included in this regression analysis. The data is for 41 countries. See Appendix 3 for details.

\section{Figure 11. Country correlations between the cyclical components of real GDP and real family programs spending}

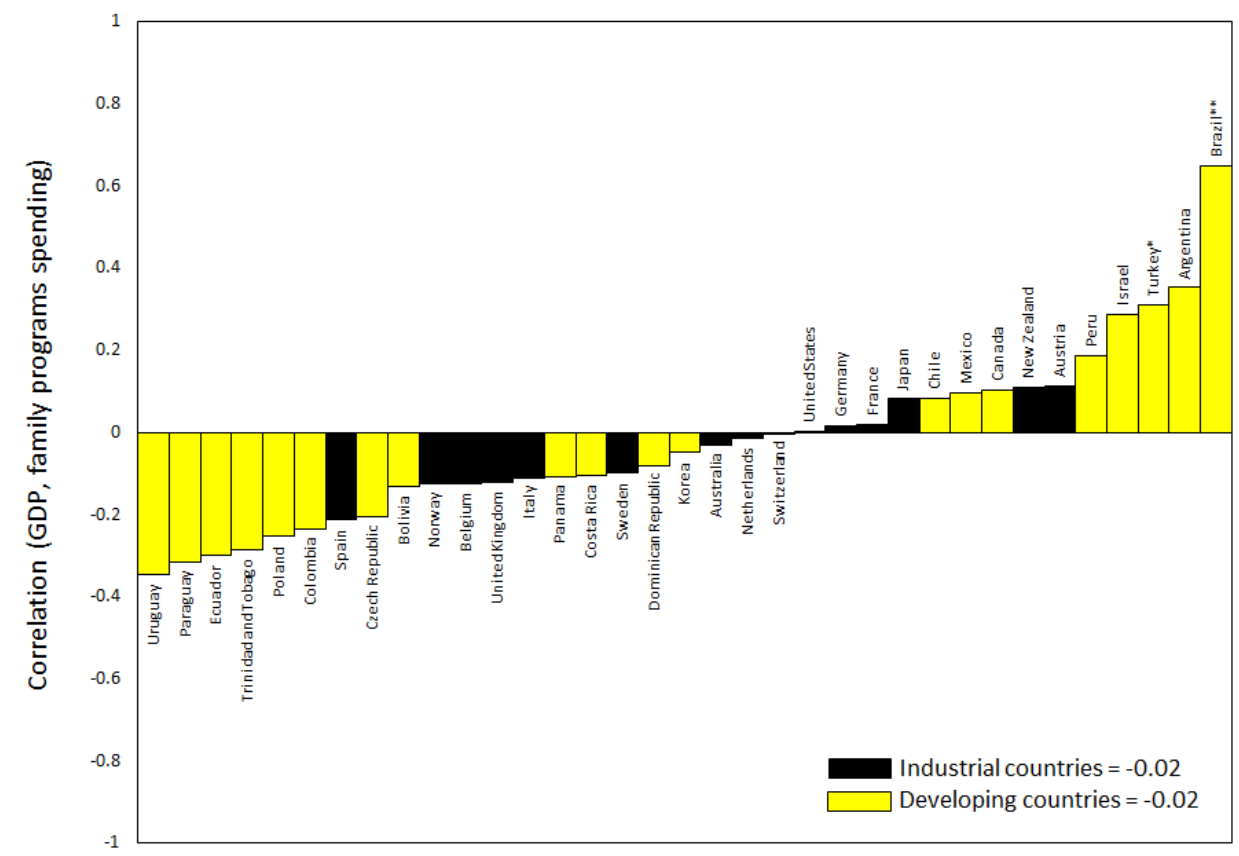

Notes: Black (yellow) bars denote industrial (developing) countries. The cyclical components have been estimated using the Hodrick-Prescott filter. A positive (negative) correlation indicates procyclical (countercyclical) family programs and benefits spending. Correlations refer to pooled across countries correlation. Real family programs spending is defined as family programs spending, deflated by the GDP deflator. See Appendix 2 for correlation values for each country. $+, *, * *$ and $* * *$ indicate statistical significance at the $15 \%, 10 \%, 5 \%$ and $1 \%$ levels, respectively.

Source: Authors' calculations based on ECLAC and OECD. ECLAC for Argentina, Bolivia, Brazil, Chile, Colombia, Costa Rica, Dominican Republic, Ecuador, Mexico, Panama, Paraguay, Peru, Trinidad and Tobago, and Uruguay. OECD for the rest of countries. See Appendix 4 for details. 35 countries for period 1980-2017. 
Figure 12. Country correlations between the cyclical components of real GDP and family programs beneficiaries (Panel A), and average real spending per beneficiary (Panel $B$ )

Panel A. Cyclicality of family programs beneficiaries

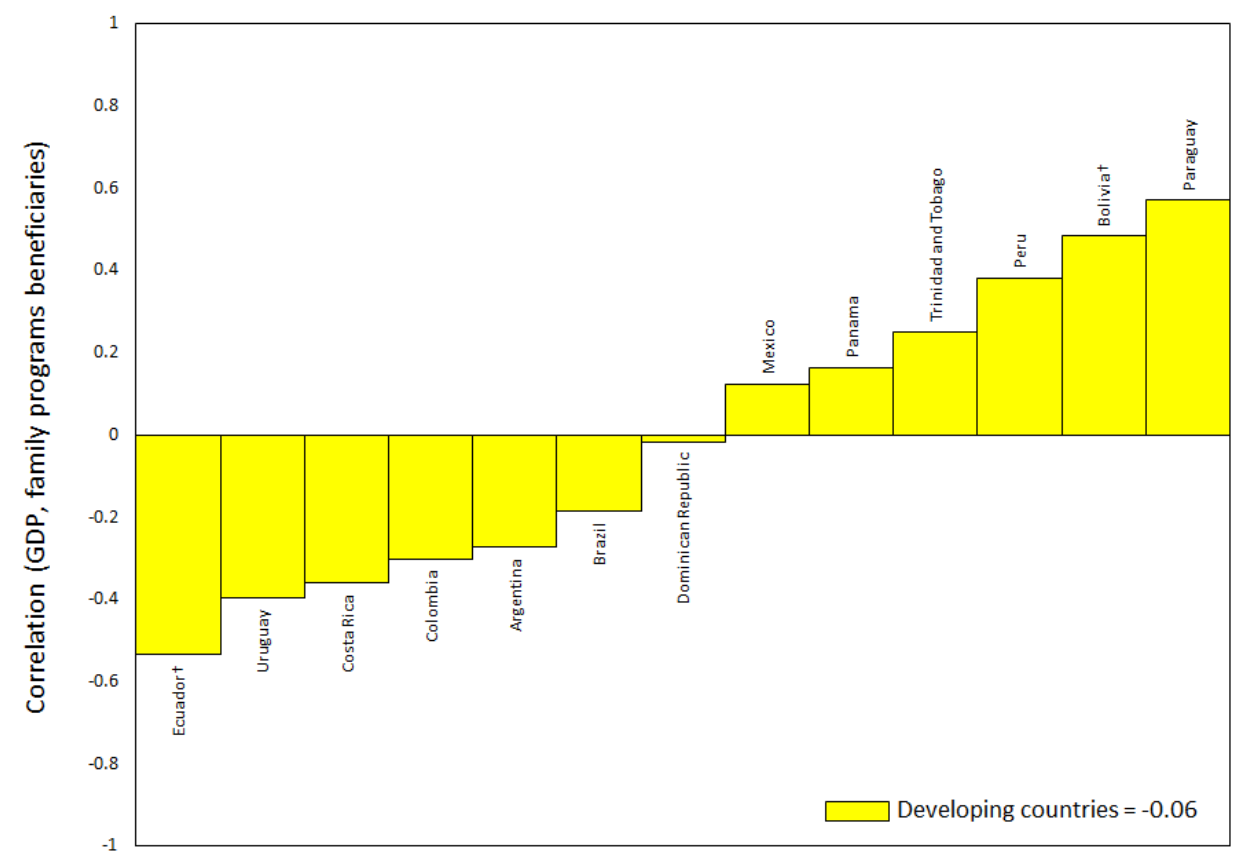

Panel B. Cyclicality of family programs average real spending per beneficiary

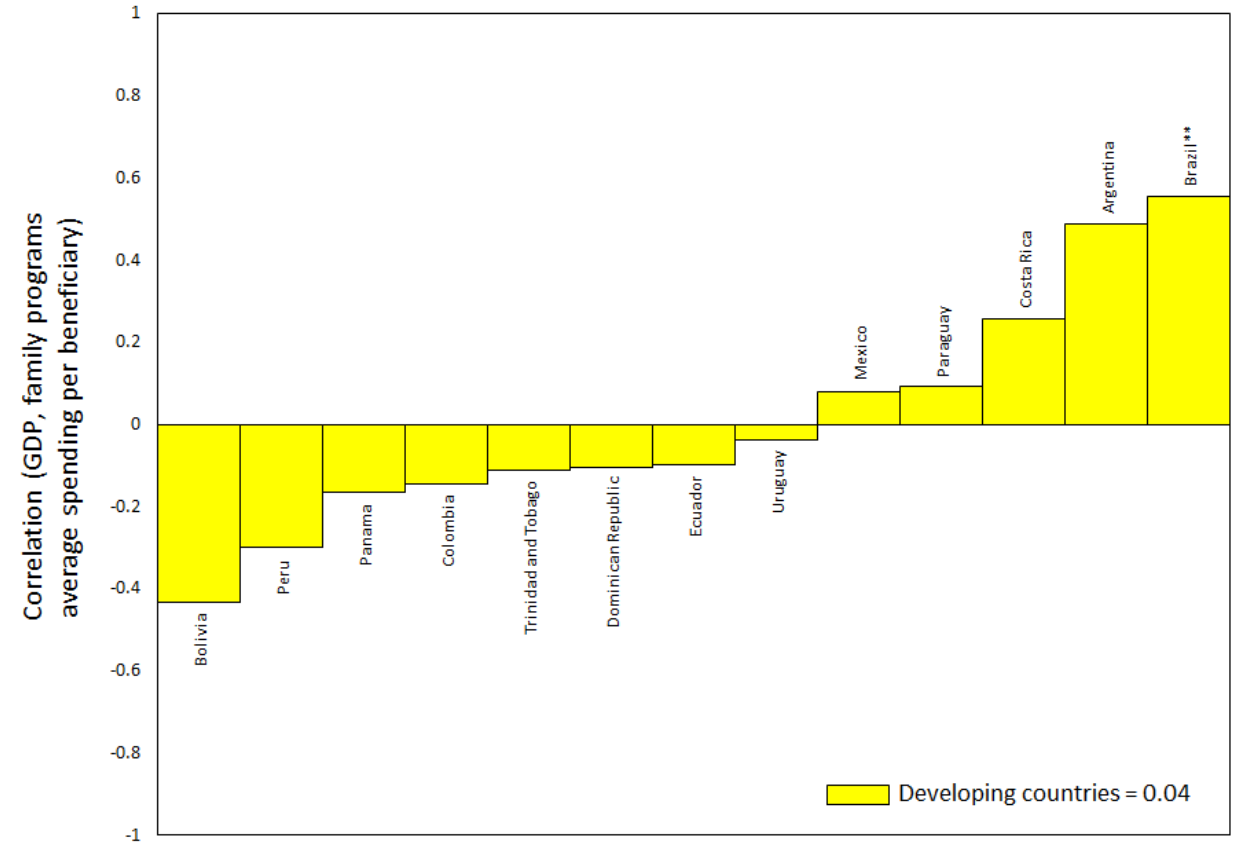

Notes: Black (yellow) bars denote industrial (developing) countries. The cyclical components have been estimated using the Hodrick-Prescott Filter. A positive (negative) correlation indicates that family programs beneficiaries in Panel A, or family programs average spending per beneficiary in Panel B, comoves positively (or negatively) with the business cycle. $+^{*},{ }^{* *}$ and ${ }^{* * *}$ indicate statistical significance at the $15 \%, 10 \%, 5 \%$ and $1 \%$ levels, respectively.

Source: Authors' calculations based on ECLAC. ECLAC for Argentina, Bolivia, Brazil, Colombia, Costa Rica, Dominican Republic, Ecuador, Mexico, Panama, Paraguay, Peru, Trinidad and Tobago, and Uruguay. See Appendix 4 for details. 14 countries for period 2002-2017 
Figure 13. Country correlations between the cyclical components of real GDP and real social security spending

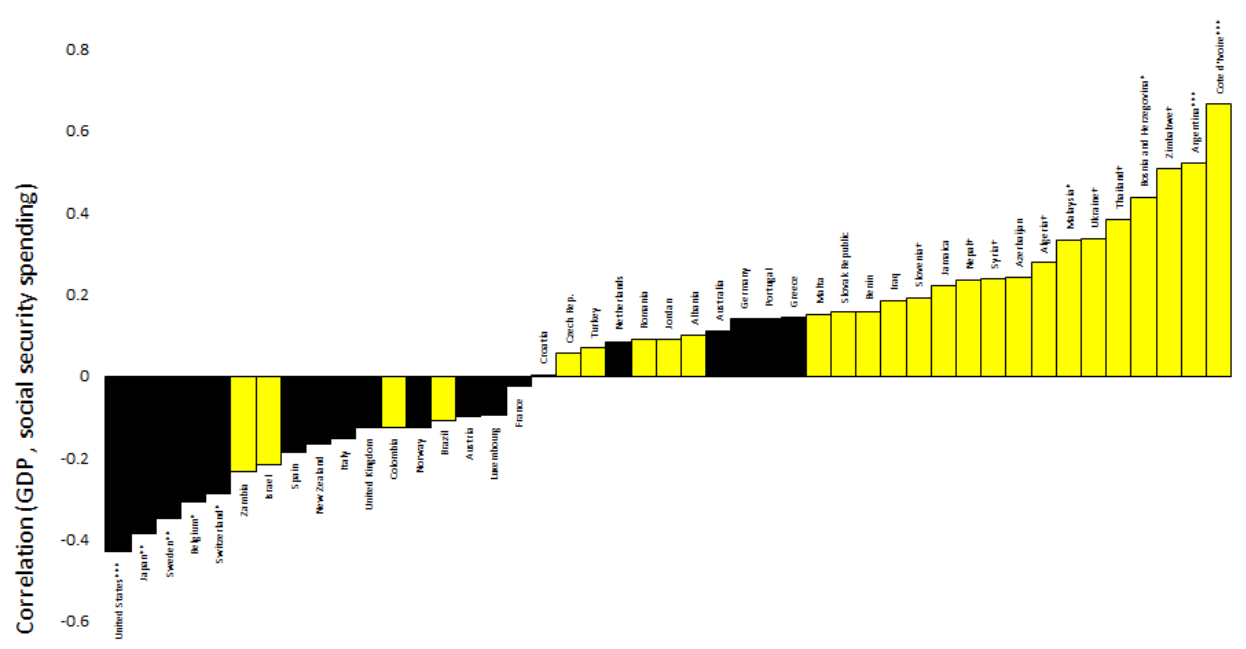

$-0.8$

Industrial countries $=-0.09^{*}$

$-1$ Developing countries $=0.13^{* * *}$

Notes: Black (yellow) bars denote industrial (developing) countries. The cyclical components have been estimated using the Hodrick-Prescott filter. A positive (negative) correlation indicates procyclical (countercyclical) social security spending. Real social security spending is defined as social security spending deflated by the GDP deflator. Correlations refer to pooled across countries correlation. See Appendix 2 for correlation values for each country. $+, *, * *$ and $* * *$ indicate statistical significance at the $15 \%, 10 \%, 5 \%$ and $1 \%$ levels, respectively.

Sources: Authors' calculations based on European System of integrated Social Protection Statistics (EuroStat), OECD, World Economic Outlook (IMF), and national sources. See Appendix 5 for details. 45 countries for period 1980-2018.

Figure 14. Country correlations between the cyclical components of real GDP and social security beneficiaries (Panel A), and average real spending per beneficiary (Panel B)

Panel A. Cyclicality of social security beneficiaries

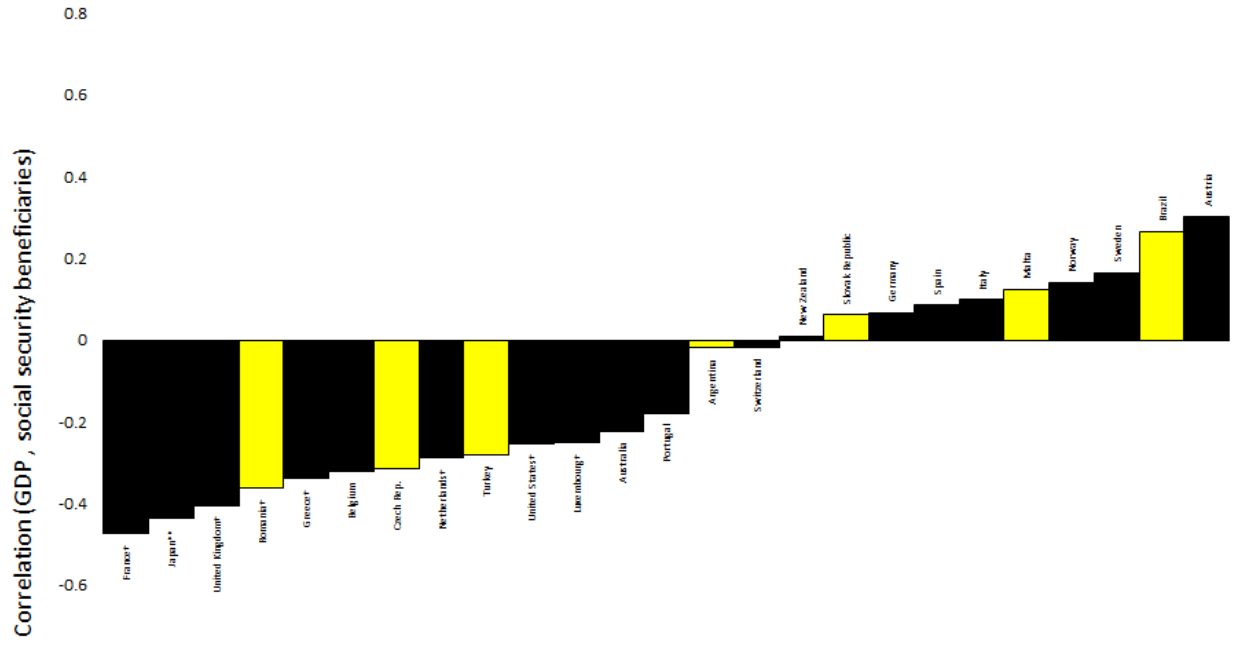

$-0.8$ 
Figure 14 (cont.). Country correlations between the cyclical components of real GDP and social security beneficiaries (Panel A), and average real spending per beneficiary (Panel B)

Panel B. Cyclicality of social security average real spending per beneficiary

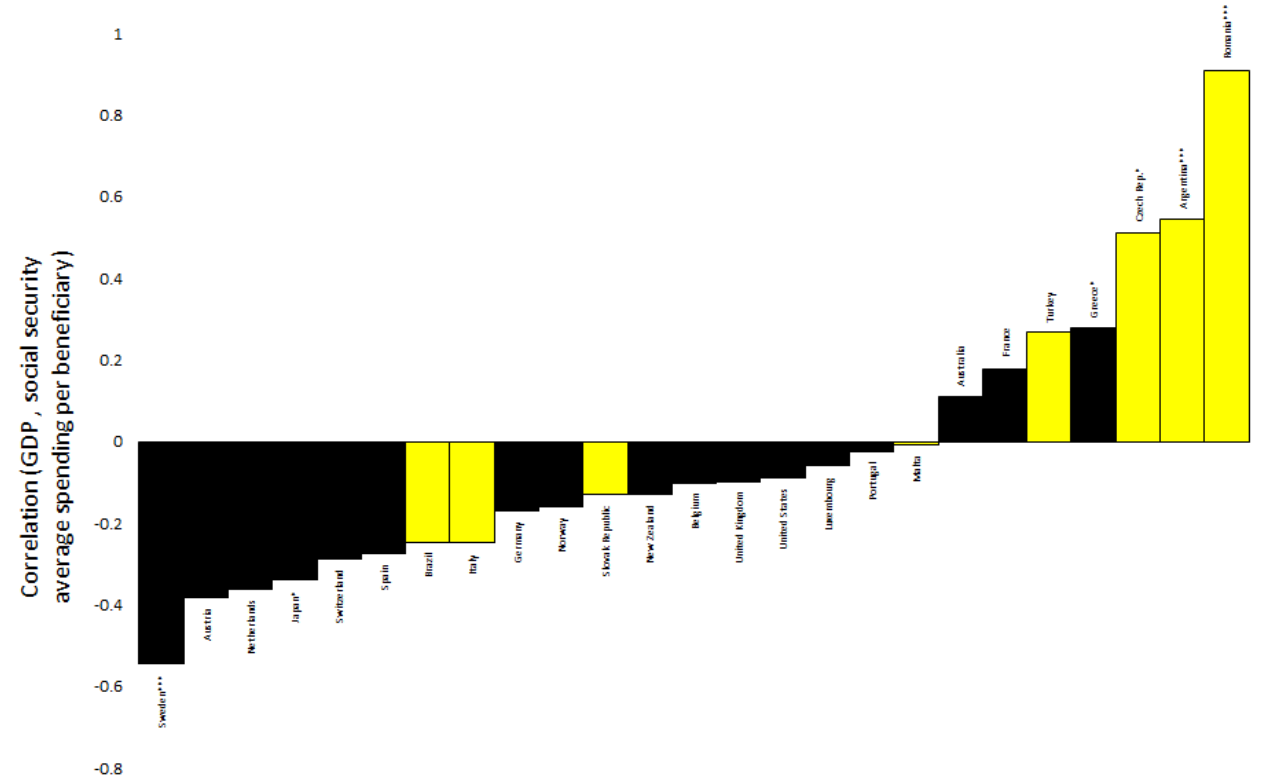

Industrial countries $=-0.08 *$

Developing countries $=0.18^{* *}$

Notes: Black (yellow) bars denote industrial (developing) countries. The cyclical components have been estimated using the Hodrick-Prescott filter. A positive (negative) correlation indicates that social security beneficiaries in Panel A, or social security average spending per beneficiary in Panel B, comoves positively (or negatively) with the business cycle. ${ }^{*}, * * *$ and ${ }^{* * *}$ indicate statistical significance at the $15 \%, 10 \%, 5 \%$ and $1 \%$ levels, respectively.

Sources: Authors' calculations based on European System of integrated Social Protection Statistics (EuroStat), OECD, World Economic Outlook (IMF), and national sources. See Appendix 5 for details. 25 countries for period 1980-2018.

Figure 15. Percentage of countries with automatic price-based formula indexation mechanisms

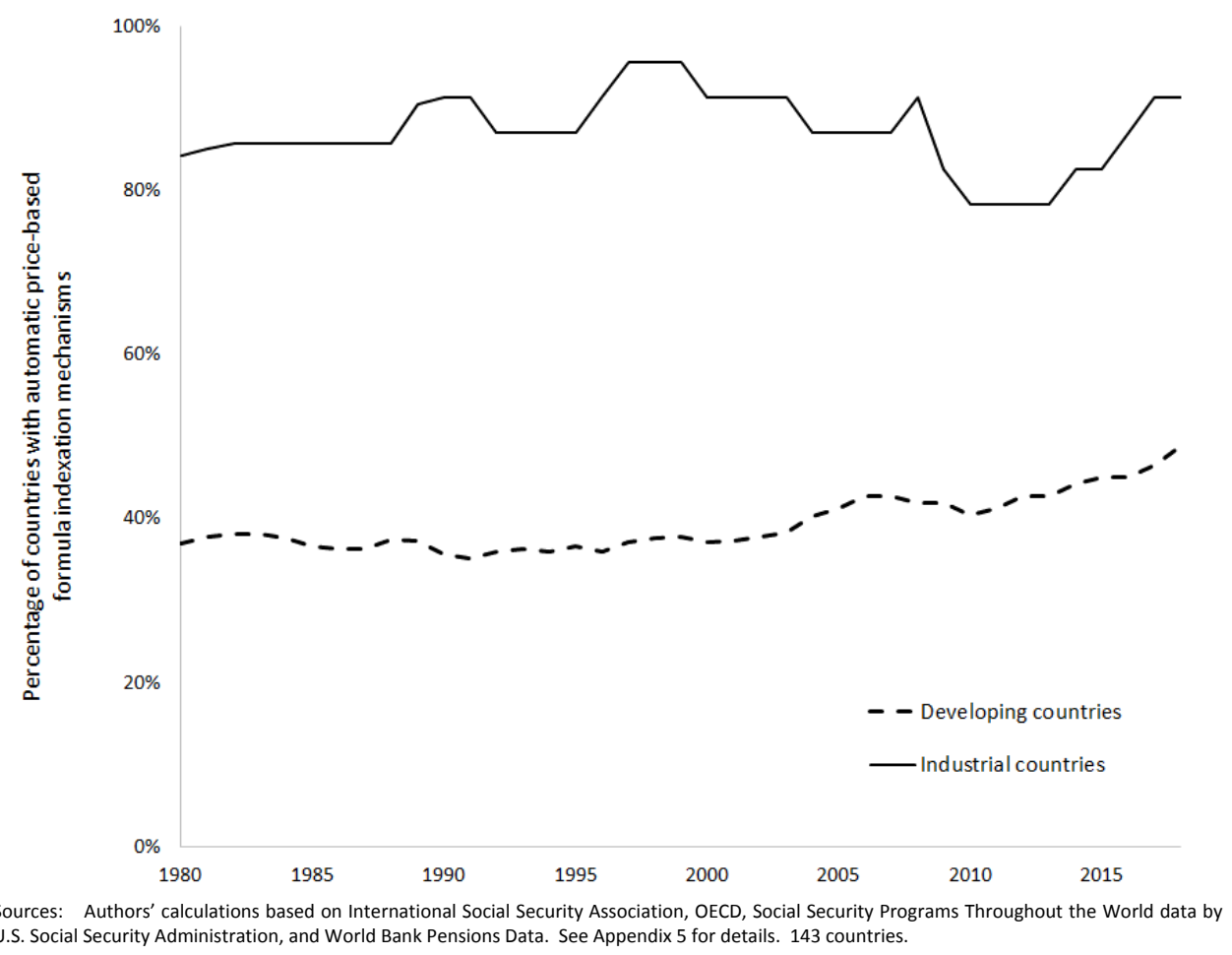


Figure 16. Existence of automatic price-based formula indexation mechanisms in the world circa 2019

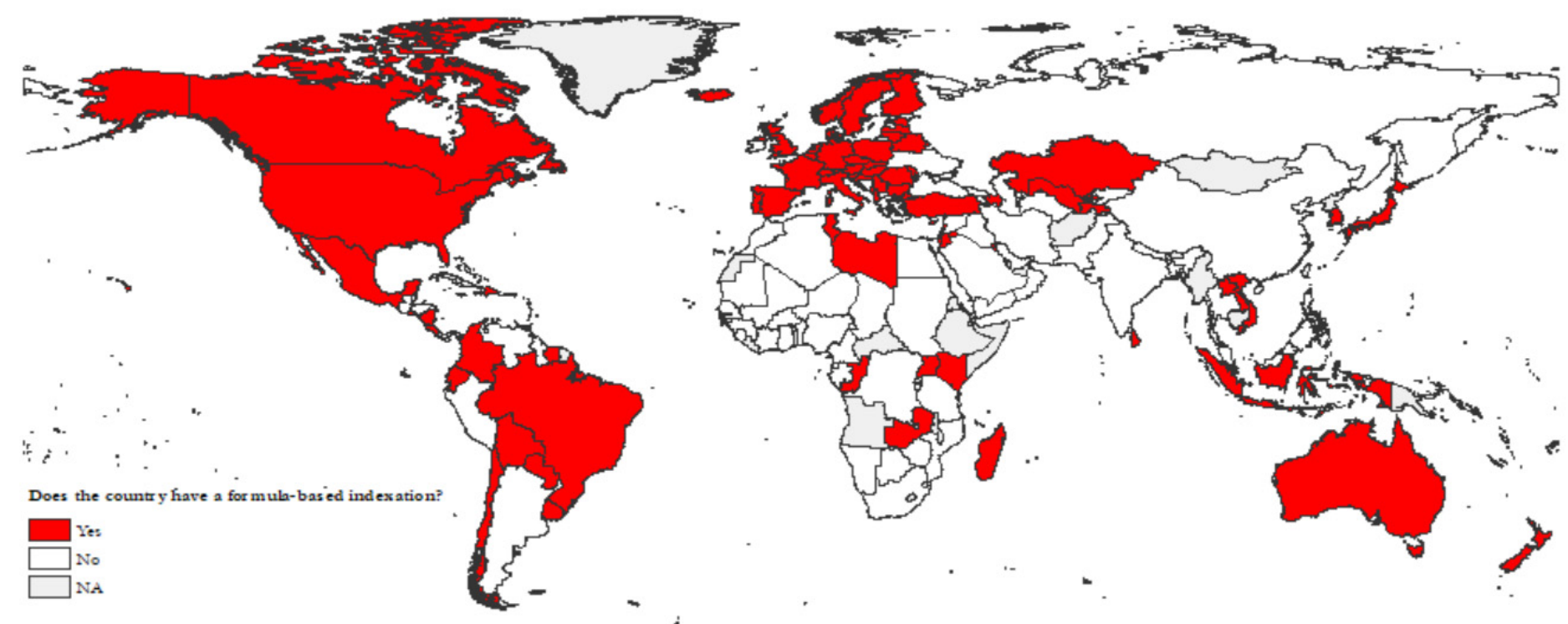

Notes: Countries in white do not have automatic price-based formula indexation mechanism. Countries in red rely on automatic price-based formula indexation mechanism.

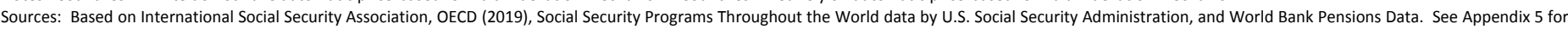
details.

Figure 17. Country correlations between the cyclical components of real GDP and real social security spending when there is an automatic price-based formula indexation mechanism (Panel $A$ ), and when countries rely on ad-hoc/discretionary criteria (Panel B)

Panel A. Country correlations between the cyclical components of real GDP and real social security spending when there is an automatic price-based formula indexation mechanism

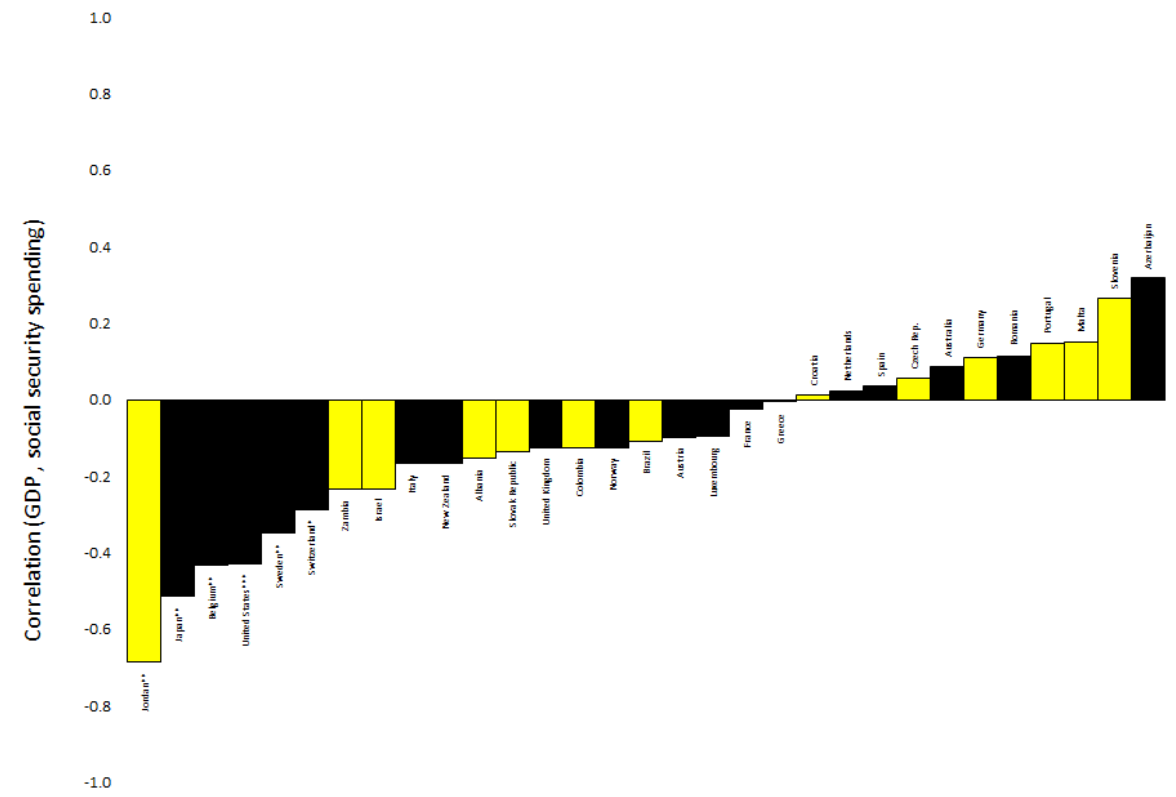


Figure 17 (cont.). Country correlations between the cyclical components of real GDP and real social security spending when there is an automatic price-based formula indexation mechanism (Panel A), and countries rely on ad-hoc/discretionary criteria (Panel B)

Panel B. Country correlations between the cyclical components of real GDP and real social security spending when countries rely on ad-hoc/discretionary criteria

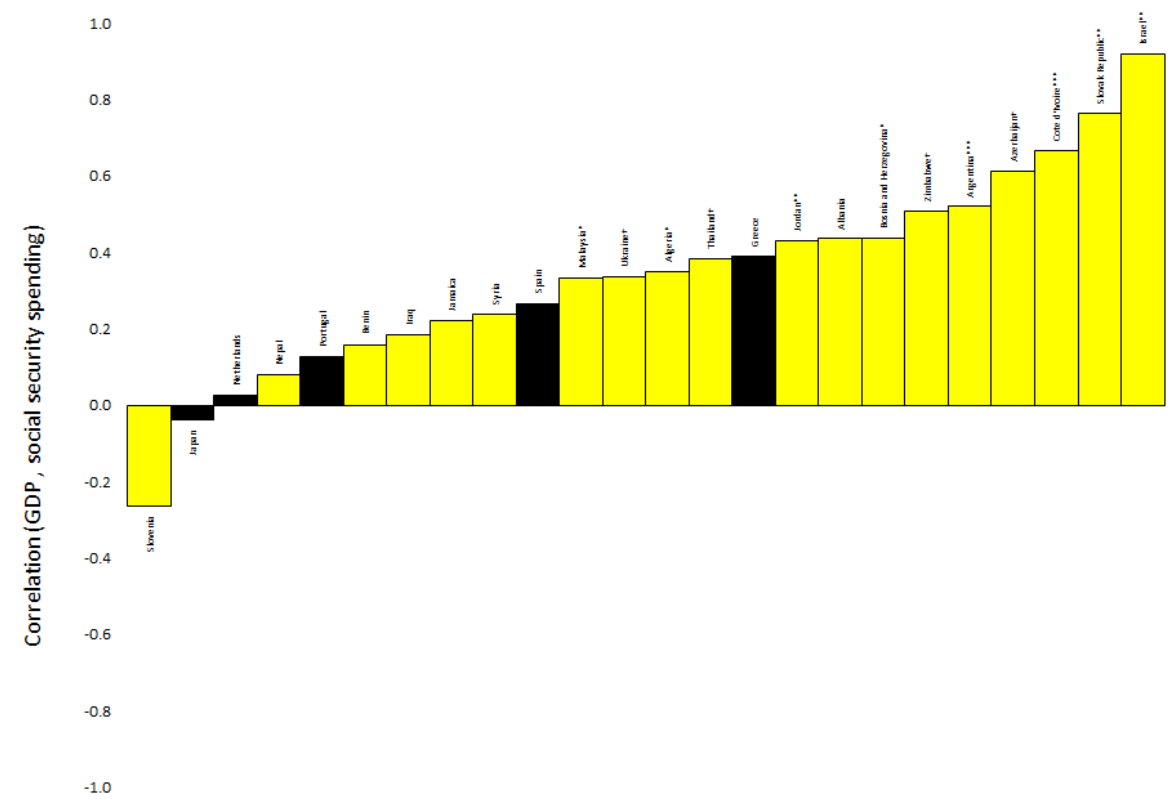

Notes: Black (yellow) bars denote industrial (developing) countries. The cyclical components have been estimated using the Hodrick-Prescott filter. A positive (negative) correlation indicates procyclical (countercyclical) social security spending. $+, *, * *$ and $* * *$ indicate statistical significance at the $15 \%, 10 \%, 5 \%$ and $1 \%$ levels, respectively.

Sources: Authors' calculations based on (i) European System of integrated Social Protection Statistics (EuroStat), OECD, World Economic Outlook (IMF), and national sources for social security spending and (ii) International Social Security Association, OECD, Social Security Programs Throughout the World data by U.S. Social Security Administration, and World Bank Pensions Data for individual social security payment adjustment mechanisms. See Appendix 5 for details. 31 countries for period 1980-2018 in Panel A and 24 countries for period $1982-2018$ in Panel B.

Figure 18. Relationship between country correlation between the cyclical components of real GDP and real social security spending and percentage of years with automatic price-based formula indexation mechanisms

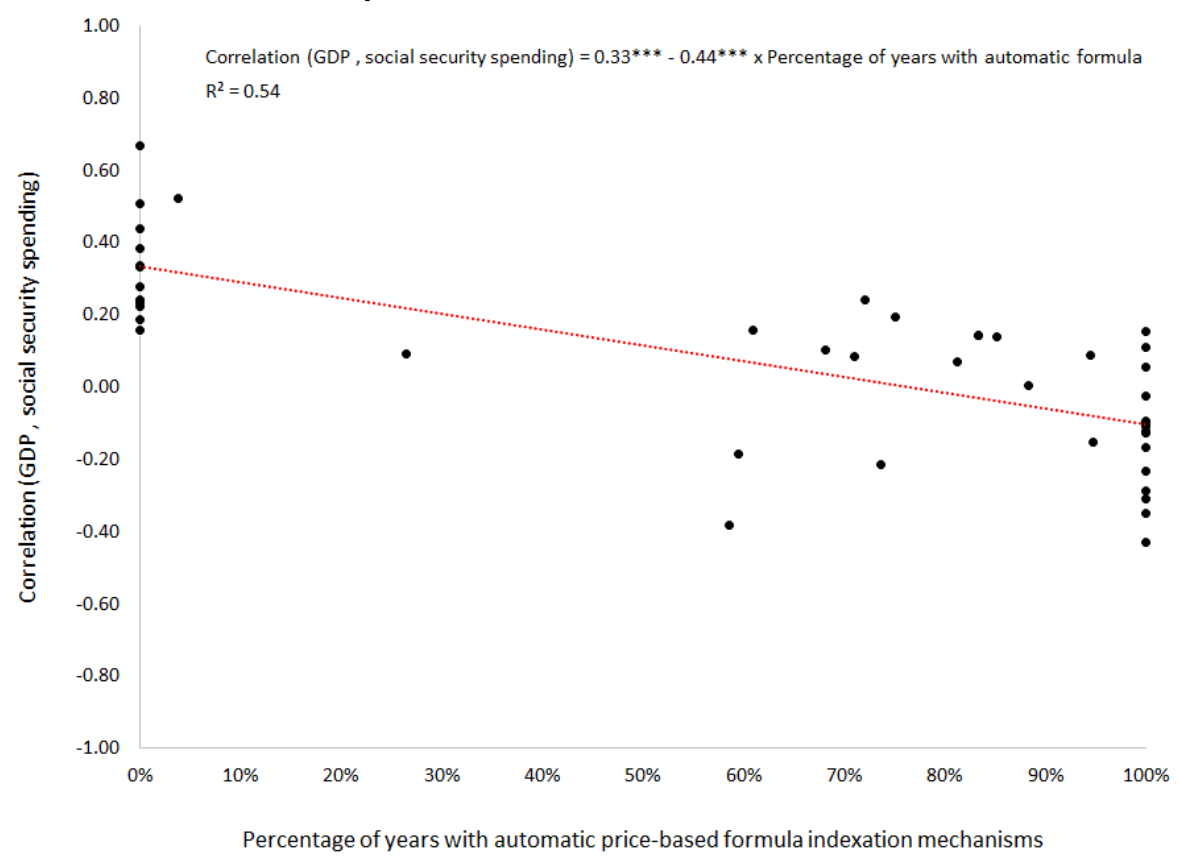

Notes: The cyclical components have been estimated using the Hodrick-Prescott filter. A positive (negative) correlation indicates procyclical (countercyclical) social security spending. Real social security spending is defined as social security spending deflated by the GDP deflator. The percentage of years with automatic price-based formula indexation mechanisms indicates the percentage of years where, according to available social security spending data, the country has had an automatic price-based formula indexation mechanism. $+, *, * *$ and $* * *$ indicate statistical significance at the $15 \%, 10 \%, 5 \%$ and $1 \%$ levels, respectively.

Sources: Authors' calculations based on (i) European System of integrated Social Protection Statistics (EuroStat), OECD, World Economic Outlook (IMF), and national sources for social security spending and (ii) International Social Security Association, OECD, Social Security Programs Throughout the World data by U.S. Social Security Administration, and World Bank Pensions Data for individual social security payment adjustment mechanisms. See Appendix 5 details. 45 countries for period 1980-2018. 
Figure 19. Relationship between country percentage of years with automatic price-based formula indexation mechanisms and percentage of years with sovereign default on external debt

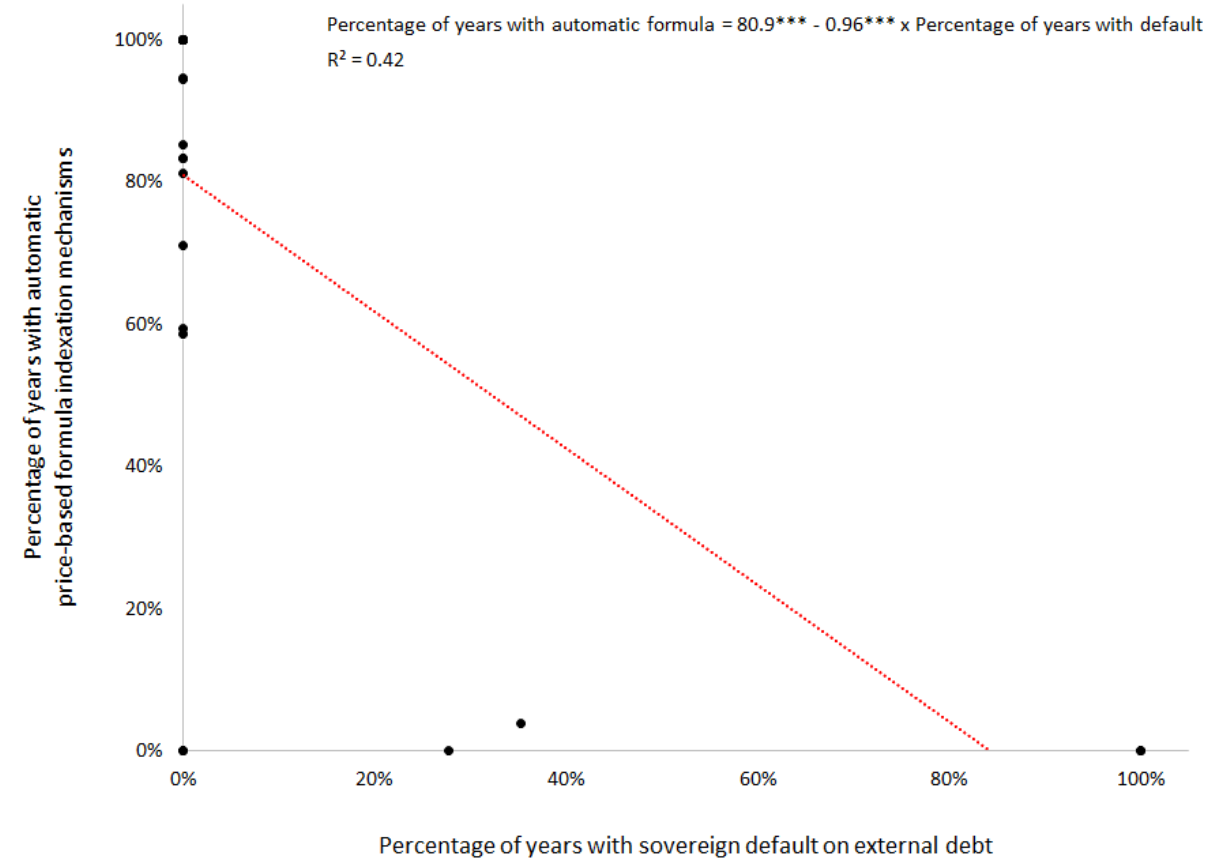

Notes: The percentage of years with automatic price-based formula indexation mechanisms indicates the percentage of years where, according to available social security spending data, the country has had an automatic price-based formula indexation mechanism. The figure only includes country observations for which we also have the correlation between the cyclical components of real GDP and real social security spending. Results do not change if all countries are considered; this exercise is, in fact, conducted later in Section 6 . $+, *, * *$ and $* * *$ indicate statistical significance at the $15 \%, 10 \%, 5 \%$ and $1 \%$ levels, respectively.

Sources: Authors' calculations based on International Social Security Association, OECD, Social Security Programs Throughout the World data by U.S. Social Security Administration, and World Bank Pensions Data for individual social security payment adjustment mechanisms. See Appendices 2 and 5 for details. 28 countries for period $1980-2018$.

Figure 20. Relationship between country percentage of years with automatic price-based formula indexation mechanisms and net financial worth from social security funds (as percentage of social security spending).

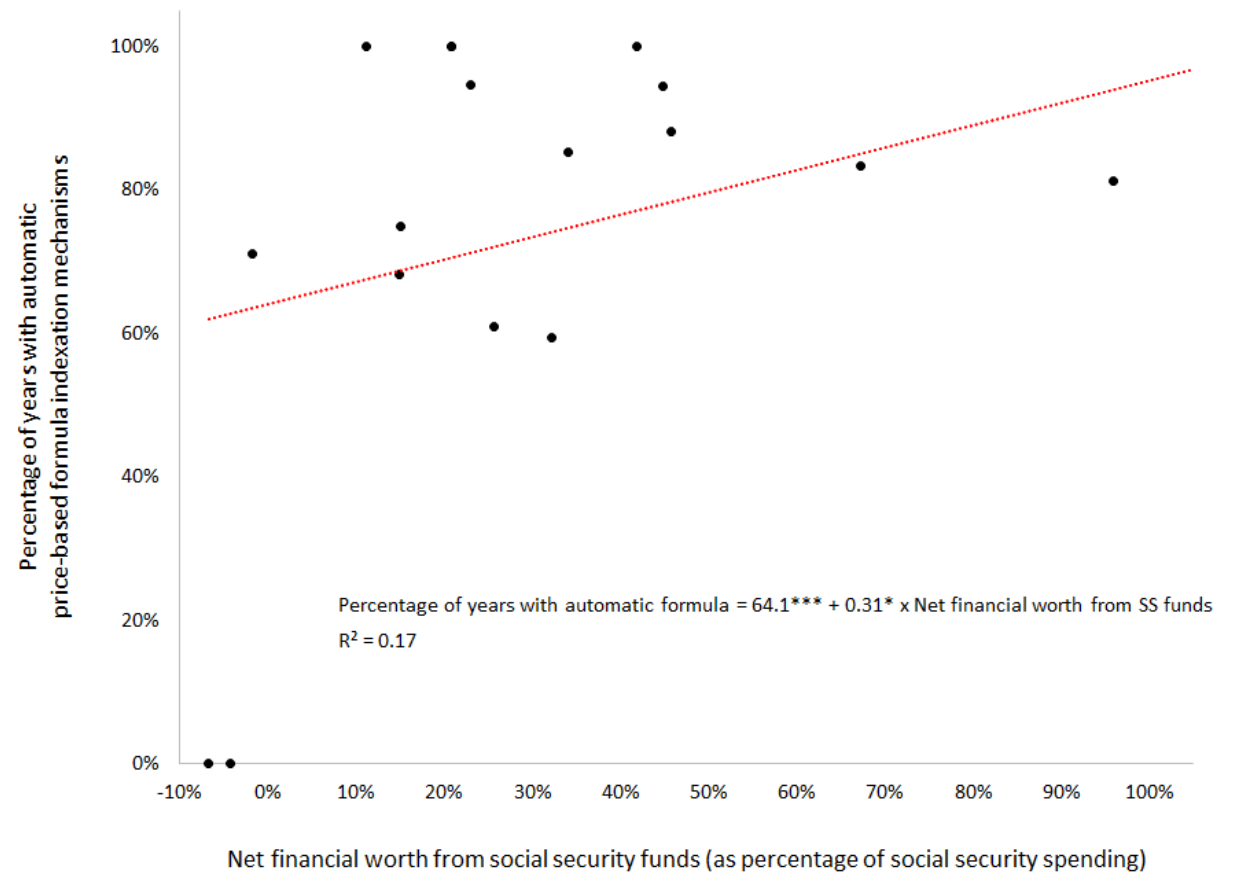

Notes: The percentage of years with automatic price-based formula indexation mechanism indicates the percentage of years where, according to available social security spending data, the country has had an automatic price-based formula indexation mechanism. The figure only includes country observations for which we also have the correlation between the cyclical components of real GDP and real social security spending. Results do not change if all countries are considered. $+, *, * *$ and ${ }^{* * *}$ indicate statistical significance at the $15 \%, 10 \%, 5 \%$ and $1 \%$ levels, respectively.

Sources: Authors' calculations based on International Social Security Association, OECD, Social Security Programs Throughout the World data by U.S. Social Security Administration and World Bank Pensions Data for individual social security payment adjustment mechanisms. See Appendices 2 and 5 for details. 19 countries for period $1980-2018$. 
Figure 21. Country correlations between the cyclical components of real social security spending and real social security revenues when there is an automatic price-based formula indexation mechanism (Panel A), and when countries rely on ad-hoc/discretionary criteria (Panel B)

Panel A. Country correlations between the cyclical components of real social security spending and real social security revenues when there is an automatic price-based formula indexation mechanism

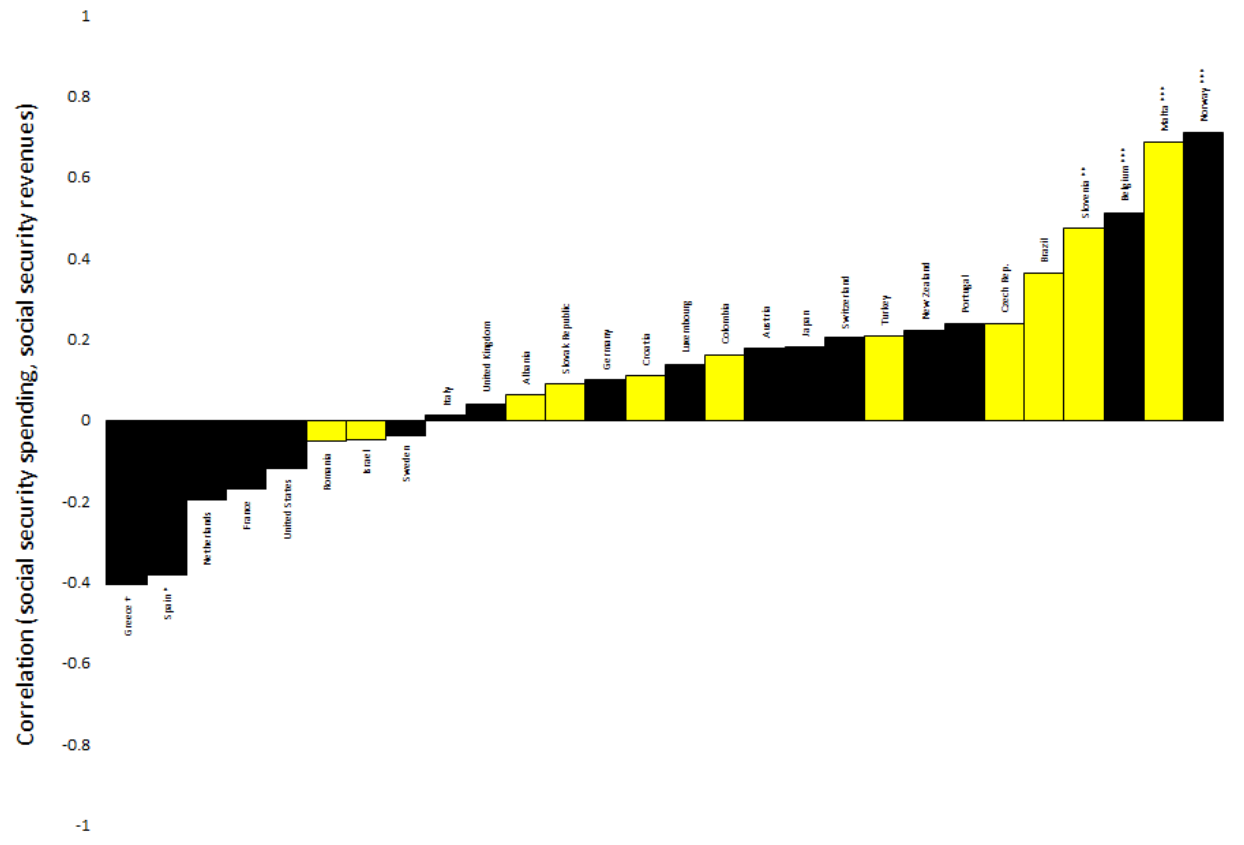

Panel B. Country correlations between the cyclical components of real social security spending and real social security revenues when countries rely on ad-hoc/discretionary criteria

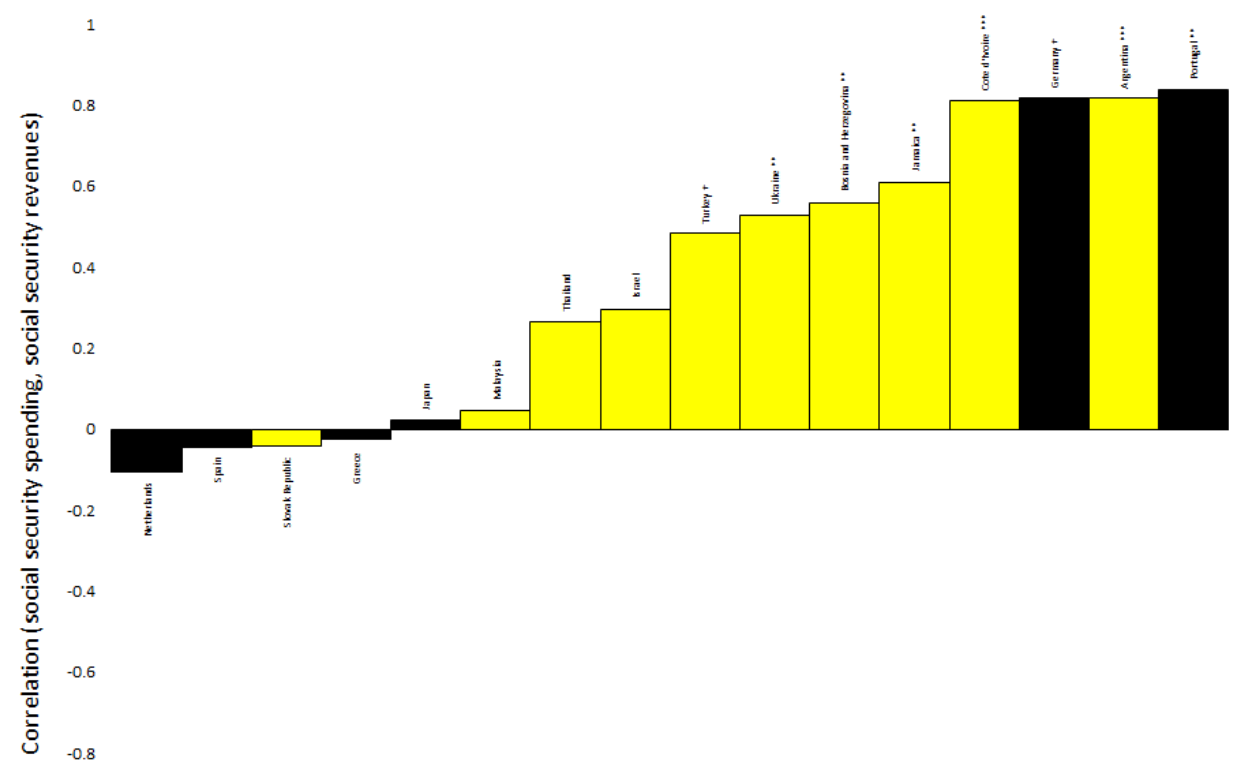

Notes: Black (yellow) bars denote industrial (developing) countries. The cyclical components have been estimated using the Hodrick-Prescott filter. A positive (negative) correlation indicates procyclical (countercyclical) social security spending. $+, *, * *$ and ${ }^{* * *}$ indicate statistical significance at the $15 \%, 10 \%, 5 \%$ and $1 \%$ levels, respectively.

Sources: Authors' calculations based on European System of integrated Social Protection Statistics (EuroStat), OECD, World Economic Outlook (IMF), and national sources. See Appendix 5 for details. 28 and 16 countries in Panels A and B, respectively, for period 1980-2018. 
Table 1. Cross-country regressions. Dependent variable is the correlation between the cyclical components of real primary spending and real GDP

Panel A. Without using instruments

\begin{tabular}{|c|c|c|c|c|c|c|c|c|}
\hline & (1) & (2) & (3) & (4) & (5) & (6) & (7) & (8) \\
\hline $\begin{array}{l}\text { Effective unemployment insurance } \\
\text { mechanism coverage }\end{array}$ & $\begin{array}{c}-1.27^{* * *} \\
{[-5.9]}\end{array}$ & & & & & $\begin{array}{c}-1.12^{* * *} \\
{[-4.1]}\end{array}$ & & $\begin{array}{c}-0.85^{* * *} \\
{[-2.7]}\end{array}$ \\
\hline $\begin{array}{l}\text { Percentage of years without automatic } \\
\text { price-based formula indexation mechanism }\end{array}$ & & $\begin{array}{c}0.25^{* * *} \\
{[3.6]}\end{array}$ & & & & & $\begin{array}{c}0.27^{* * *} \\
{[3.6]}\end{array}$ & $\begin{array}{c}0.18^{* *} \\
{[2.4]}\end{array}$ \\
\hline Insitutional quality & & & $\begin{array}{l}-1.36^{* * *} \\
{[-10.4]}\end{array}$ & & & $\begin{array}{c}-1.19^{* * *} \\
{[-4.8]}\end{array}$ & $\begin{array}{c}-1.22^{* * *} \\
{[-5.0]}\end{array}$ & $\begin{array}{c}-1.10^{* * *} \\
{[-3.8]}\end{array}$ \\
\hline Financial integration & & & & $\begin{array}{c}-0.10^{* * *} \\
{[-3.3]}\end{array}$ & & $\begin{array}{l}-0.01 \\
{[-0.2]}\end{array}$ & $\begin{array}{r}0.01 \\
{[0.1]}\end{array}$ & $\begin{array}{l}-0.01 \\
{[-0.1]}\end{array}$ \\
\hline Checks and balances & & & & & $\begin{array}{c}-0.10^{* * *} \\
{[-4.1]}\end{array}$ & $\begin{array}{l}-0.04 \\
{[-1.2]}\end{array}$ & $\begin{array}{l}-0.02 \\
{[-0.7]}\end{array}$ & $\begin{array}{l}-0.04 \\
{[-1.0]}\end{array}$ \\
\hline Observations & 107 & 116 & 109 & 129 & 128 & 93 & 100 & 86 \\
\hline$R^{2}$ & 0.20 & 0.11 & 0.47 & 0.09 & 0.12 & 0.47 & 0.43 & 0.45 \\
\hline
\end{tabular}

Panel B. Using instruments

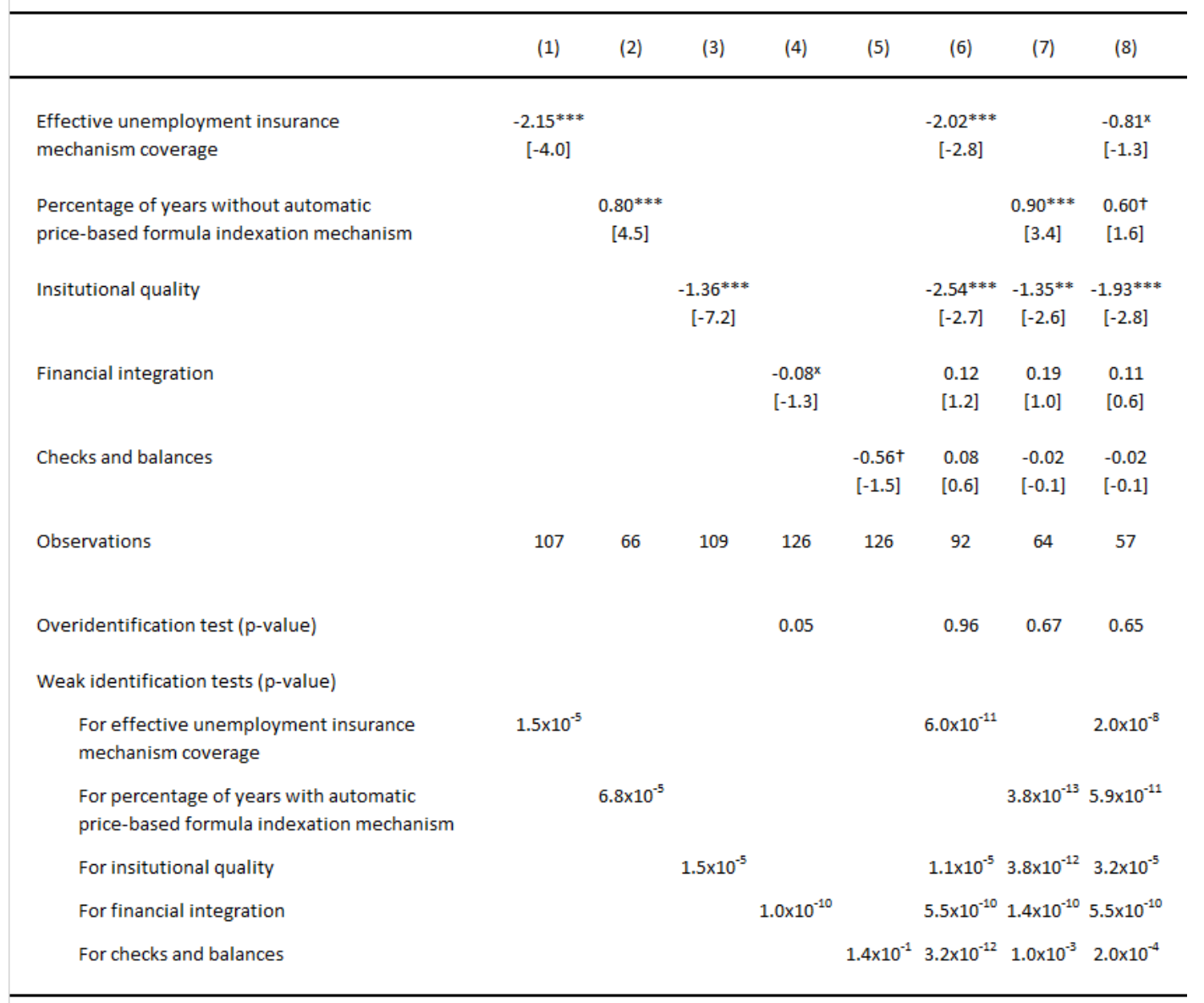

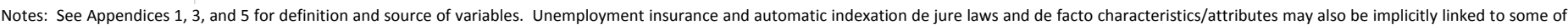

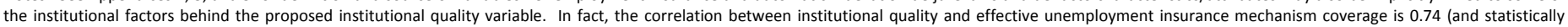

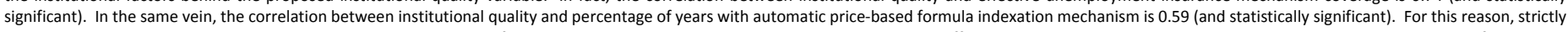

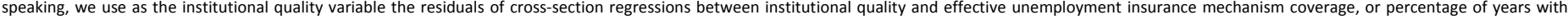

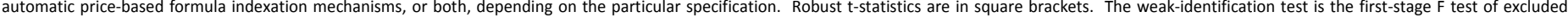

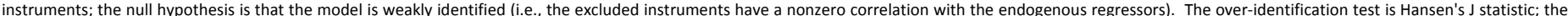

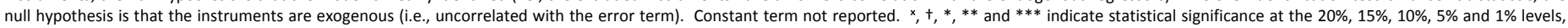
respectively. 
Table 2. Cross-country regressions. Dependent variables are effective unemployment insurance mechanism coverage, percentage of years with automatic price-based formula indexation mechanism, financial integration, and checks and balances

Panel A: Dependent variable is effective unemployment insurance mechanism coverage

\begin{tabular}{|c|c|c|c|c|c|c|}
\hline & (1) & (2) & (3) & (4) & (5) & (6) \\
\hline Agriculture in GDP & $-0.38^{* * *}$ & & & & & -0.05 \\
\hline circa 1950 & {$[-5.7]$} & & & & & {$[-0.6]$} \\
\hline Sovereign external default & & -0.05 & & & & 0.02 \\
\hline in 1960-1975 & & {$[-0.3]$} & & & & {$[0.2]$} \\
\hline \multirow[t]{2}{*}{ Latitude } & & & $0.46^{* * *}$ & & & $0.45^{* * *}$ \\
\hline & & & {$[7.7]$} & & & [5.5] \\
\hline \multirow[t]{2}{*}{ British colonial dummy } & & & & $-0.14^{* * *}$ & & $-0.09^{* *}$ \\
\hline & & & & {$[-4.1]$} & & {$[-2.4]$} \\
\hline \multirow[t]{2}{*}{ French colonial dummy } & & & & $-0.07^{* * *}$ & & $-0.13^{* * *}$ \\
\hline & & & & {$[-2.9]$} & & {$[-2.7]$} \\
\hline \multirow[t]{2}{*}{ French legal origin dummy } & & & & $-0.09^{* *}$ & & 0.01 \\
\hline & & & & {$[-2.3]$} & & [0.3] \\
\hline \multirow[t]{2}{*}{ Democracy in 1900} & & & & & 0.04 & $0.27^{* * *}$ \\
\hline & & & & & {$[0.8]$} & {$[2.8]$} \\
\hline Observations & 107 & 61 & 107 & 105 & 106 & 61 \\
\hline$R^{2}$ & 0.24 & 0.00 & 0.51 & 0.23 & 0.01 & 0.65 \\
\hline
\end{tabular}

Panel C: Dependent variable is institutional quality

\begin{tabular}{|c|c|c|c|c|c|c|}
\hline $\begin{array}{l}\text { Agriculture in GDP } \\
\text { circa } 1950\end{array}$ & $\begin{array}{l}-0.75^{* * *} \\
{[-8.2]}\end{array}$ & & & & & $\begin{array}{c}-0.55^{* * *} \\
{[-3.2]}\end{array}$ \\
\hline $\begin{array}{l}\text { Sovereign external default } \\
\text { in } 1960-1975\end{array}$ & & $\begin{array}{l}-0.34^{* * *} \\
{[-3.6]}\end{array}$ & & & & $\begin{array}{c}-0.23^{* * *} \\
{[-3.1]}\end{array}$ \\
\hline Latitude & & & $\begin{array}{c}0.64^{* * *} \\
{[9.2]}\end{array}$ & & & $\begin{array}{c}0.35^{* * *} \\
{[3.4]}\end{array}$ \\
\hline British colonial dummy & & & & $\begin{array}{c}-0.11^{* * *} \\
{[-2.7]}\end{array}$ & & $\begin{array}{l}-0.04 \\
{[-1.0]}\end{array}$ \\
\hline French colonial dummy & & & & $\begin{array}{c}-0.12^{* * *} \\
{[-3.5]}\end{array}$ & & $\begin{array}{c}-0.07^{*} \\
{[-1.7]}\end{array}$ \\
\hline French legal origin dummy & & & & $\begin{array}{c}-0.14^{* * *} \\
{[-3.7]}\end{array}$ & & $\begin{array}{l}-0.06^{*} \\
{[-1.7]}\end{array}$ \\
\hline Democracy in 1900 & & & & & $\begin{array}{c}0.19^{* * *} \\
{[2.7]}\end{array}$ & $\begin{array}{c}0.26^{* * *} \\
{[3.6]}\end{array}$ \\
\hline Observations & 109 & 67 & 109 & 109 & 107 & 67 \\
\hline$R^{2}$ & 0.43 & 0.09 & 0.48 & 0.21 & 0.05 & 0.74 \\
\hline
\end{tabular}

Panel E: Dependent variable is checks and balances

\begin{tabular}{|c|c|c|c|c|c|c|}
\hline $\begin{array}{l}\text { Agriculture in GDP } \\
\text { circa } 1950\end{array}$ & $\begin{array}{c}-3.11^{* * *} \\
{[-5.1]}\end{array}$ & & & & & $\begin{array}{l}-0.71 \\
{[-0.4]}\end{array}$ \\
\hline Sovereign external default & & -0.42 & & & & 0.37 \\
\hline in $1960-1975$ & & {$[-0.6]$} & & & & {$[0.4]$} \\
\hline Latitude & & & $\begin{array}{c}2.80^{* * *} \\
{[6.1]}\end{array}$ & & & $\begin{array}{c}1.77^{* *} \\
{[2.4]}\end{array}$ \\
\hline British colonial dummy & & & & $\begin{array}{l}-0.36 \\
{[-1.3]}\end{array}$ & & $\begin{array}{r}-0.19 \\
{[-0.5]}\end{array}$ \\
\hline French colonial dummy & & & & $\begin{array}{l}-1.11^{* * *} \\
{[-5.6]}\end{array}$ & & $\begin{array}{c}-1.75^{* *} \\
{[-2.6]}\end{array}$ \\
\hline French legal origin dummy & & & & $\begin{array}{c}-0.50^{* *} \\
{[-2.1]}\end{array}$ & & $\begin{array}{l}0.16 \\
{[0.5]}\end{array}$ \\
\hline Democracy in 1900 & & & & & $\begin{array}{l}0.83^{\dagger} \\
{[1.5]}\end{array}$ & $\begin{array}{l}1.84^{*} \\
{[1.8]}\end{array}$ \\
\hline Observations & 128 & 70 & 128 & 126 & 126 & 70 \\
\hline $\mathrm{R}^{2}$ & 0.16 & 0.00 & 0.19 & 0.18 & 0.02 & 0.34 \\
\hline
\end{tabular}

Panel $B$ : Dependent variable is percentage of years without automatic price-based formula indexation mechanism

\begin{tabular}{|c|c|c|c|c|c|c|}
\hline & (1) & (2) & (3) & (4) & (5) & (6) \\
\hline Agriculture in GDP & $1.19^{* * *}$ & & & & & 0.47 \\
\hline circa 1950 & [4.9] & & & & & {$[0.8]$} \\
\hline Sovereign external default & & $1.08^{* * *}$ & & & & $0.99^{* * *}$ \\
\hline in $1960-1975$ & & [4.3] & & & & [4.9] \\
\hline \multirow[t]{2}{*}{ Latitude } & & & $-0.91^{* * *}$ & & & $-0.61 \dagger$ \\
\hline & & & {$[-4.7]$} & & & {$[-1.7]$} \\
\hline \multirow{2}{*}{ British colonial dummy } & & & & $0.23^{* *}$ & & 0.16 \\
\hline & & & & {$[2.2]$} & & [0.9] \\
\hline \multirow[t]{2}{*}{ French colonial dummy } & & & & $0.21 \dagger$ & & 0.19 \\
\hline & & & & [1.6] & & {$[0.7]$} \\
\hline \multirow[t]{2}{*}{ French legal origin dummy } & & & & 0.05 & & -0.10 \\
\hline & & & & {$[0.5]$} & & {$[-0.8]$} \\
\hline \multirow[t]{2}{*}{ Democracy in 1900} & & & & & -0.22 & -0.20 \\
\hline & & & & & {$[-1.1]$} & {$[-0.6]$} \\
\hline Observations & 116 & 66 & 116 & 114 & 114 & 66 \\
\hline$R^{2}$ & 0.15 & 0.16 & 0.15 & 0.06 & 0.01 & 0.36 \\
\hline
\end{tabular}

Panel D: Dependent variable is financial integration

\begin{tabular}{|c|c|c|c|c|c|c|}
\hline $\begin{array}{l}\text { Agriculture in GDP } \\
\text { circa } 1950\end{array}$ & $\begin{array}{c}-3.46^{* * *} \\
{[-5.4]}\end{array}$ & & & & & $\begin{array}{c}-3.86^{* * *} \\
{[-3.7]}\end{array}$ \\
\hline Sovereign external default & & $-1.66^{* *}$ & & & & $-1.20^{* *}$ \\
\hline in $1960-1975$ & & {$[-2.1]$} & & & & {$[-2.3]$} \\
\hline Latitude & & & $\begin{array}{c}2.20^{* * *} \\
{[5.1]}\end{array}$ & & & $\begin{array}{l}0.15 \\
{[0.2]}\end{array}$ \\
\hline British colonial dummy & & & & $\begin{array}{c}-0.69^{* * *} \\
{[-3.1]}\end{array}$ & & $\begin{array}{c}-0.42 \\
{[-1.3]}\end{array}$ \\
\hline French colonial dummy & & & & $\begin{array}{c}-1.03^{* * *} \\
{[-5.4]}\end{array}$ & & $\begin{array}{l}-1.15^{* * *} \\
{[-3.6]}\end{array}$ \\
\hline French legal origin dummy & & & & $\begin{array}{l}-0.46^{* *} \\
{[-2.2]}\end{array}$ & & $\begin{array}{r}-0.04 \\
{[-0.2]}\end{array}$ \\
\hline Democracy in 1900 & & & & & $\begin{array}{r}-0.36 \\
{[-0.8]}\end{array}$ & $\begin{array}{l}0.95 \dagger \\
{[1.6]}\end{array}$ \\
\hline Observations & 129 & 70 & 129 & 126 & 128 & 70 \\
\hline$R^{2}$ & 0.27 & 0.07 & 0.16 & 0.21 & 0.01 & 0.48 \\
\hline
\end{tabular}

Notes: See Appendices 1,3 , and 5 for definitions and sources of variables. Robust t-statistics are in square brackets. Constant term not reported. ${ }^{*},+, *, * *$ and $* * *$ indicate statistical significance at the $20 \%, 15 \%, 10 \%, 5 \%$ and $1 \%$ levels, respectively. 
Table 3. Cross-country regressions. Dependent variable is macroeconomic volatility measured by the standard deviation of annual real GDP growth

Panel A. Without using instruments

\begin{tabular}{|c|c|c|c|c|c|c|c|c|c|c|}
\hline & (1) & (2) & (3) & (4) & (5) & (6) & (7) & (8) & (9) & (10) \\
\hline Primary spending/GDP & $\begin{array}{c}-0.05^{* * *} \\
{[-3.5]}\end{array}$ & & & & & $\begin{array}{c}-0.03^{*} \\
{[-1.7]}\end{array}$ & & & & \\
\hline Discretionary spending/GDP & & $\begin{array}{l}0.03 \\
{[1.0]}\end{array}$ & $\begin{array}{l}0.04 \\
{[1.1]}\end{array}$ & $\begin{array}{l}0.03 \\
{[1.0]}\end{array}$ & $\begin{array}{l}0.00 \\
{[0.1]}\end{array}$ & & $\begin{array}{l}0.03 \\
{[0.9]}\end{array}$ & $\begin{array}{l}0.03 \\
{[0.9]}\end{array}$ & $\begin{array}{l}0.03 \\
{[1.1]}\end{array}$ & $\begin{array}{l}0.01 \\
{[0.2]}\end{array}$ \\
\hline Automatic spending/GDP & & $\begin{array}{l}-0.10^{* * *} \\
{[-4.9]}\end{array}$ & & & & & $\begin{array}{c}-0.07^{* * *} \\
{[-2.8]}\end{array}$ & & & \\
\hline $\begin{array}{l}\text { Automatic spending/GDP } \\
\text { (when unemployment insurance is absent) }\end{array}$ & & & $\begin{array}{l}-0.04 \\
{[-0.6]}\end{array}$ & & & & & $\begin{array}{l}-0.06 \\
{[-1.0]}\end{array}$ & & \\
\hline $\begin{array}{l}\text { Automatic spending/GDP } \\
\text { (when unemployment insurance is present) }\end{array}$ & & & $\begin{array}{c}-0.09^{* * *} \\
{[-3.8]}\end{array}$ & & & & & $\begin{array}{l}-0.07^{* * *} \\
{[-2.6]}\end{array}$ & & \\
\hline $\begin{array}{l}\text { Automatic spending/GDP } \\
\text { (when social security formula indexation is absent) }\end{array}$ & & & & $\begin{array}{l}0.02 \\
{[0.7]}\end{array}$ & & & & & $\begin{array}{l}0.01 \\
{[0.4]}\end{array}$ & \\
\hline $\begin{array}{l}\text { Automatic spending/GDP } \\
\text { (when social security formula indexation is present) }\end{array}$ & & & & $\begin{array}{c}-0.07^{* * *} \\
{[-4.2]}\end{array}$ & & & & & $\begin{array}{l}-0.06^{* * *} \\
{[-2.9]}\end{array}$ & \\
\hline $\begin{array}{l}\text { Automatic spending/GDP } \\
\text { (when unemployment insurance and } \\
\text { social security formula indexation are both absent) }\end{array}$ & & & & & $\begin{array}{l}0.02 \\
{[0.4]}\end{array}$ & & & & & $\begin{array}{l}0.00 \\
{[0.0]}\end{array}$ \\
\hline $\begin{array}{l}\text { Automatic spending/GDP } \\
\text { (when unemployment insurance is absent and } \\
\text { social security formula indexation is present) }\end{array}$ & & & & & $\begin{array}{r}-0.10 \\
{[-1.2]}\end{array}$ & & & & & $\begin{array}{r}-0.11 \\
{[-1.3]}\end{array}$ \\
\hline $\begin{array}{l}\text { Automatic spending/GDP } \\
\text { (when unemployment insurance is present and } \\
\text { social security formula indexation is absent) }\end{array}$ & & & & & $\begin{array}{l}-0.02 \\
{[-0.2]}\end{array}$ & & & & & $\begin{array}{r}-0.02 \\
{[-0.3]}\end{array}$ \\
\hline $\begin{array}{l}\text { Automatic spending/GDP } \\
\text { (when unemployment insurance and } \\
\text { social security formula indexation are both present) }\end{array}$ & & & & & $\begin{array}{c}-0.07^{* * *} \\
{[-3.6]}\end{array}$ & & & & & $\begin{array}{l}-0.08^{* * *} \\
{[-2.9]}\end{array}$ \\
\hline Terms of trade volatility & & & & & & $\begin{array}{c}0.07^{* * *} \\
{[2.8]}\end{array}$ & $\begin{array}{l}0.05 \dagger \\
{[1.5]}\end{array}$ & $\begin{array}{l}0.05^{x} \\
{[1.4]}\end{array}$ & $\begin{array}{l}0.03 \\
{[0.9]}\end{array}$ & $\begin{array}{l}0.00 \\
{[0.1]}\end{array}$ \\
\hline Observations & 125 & 102 & 102 & 92 & 73 & 122 & 100 & 100 & 91 & 72 \\
\hline$R^{2}$ & 0.07 & 0.19 & 0.20 & 0.25 & 0.28 & 0.14 & 0.21 & 0.21 & 0.25 & 0.27 \\
\hline
\end{tabular}

Notes: See Appendices 1,3 , and 5 for definition and source of variables. Robust t-statistics are in square brackets. Constant term not reported. ${ }^{x},+, *, * *$ and $* * *$ indicate statistical significance at the $20 \%, 15 \%, 10 \%, 5 \%$ and $1 \%$ levels, respectively. 
Table 3 (cont.). Cross-country regressions. Dependent variable is macroeconomic volatility measured by the standard deviation of annual real GDP growth

Panel B. Using instruments

\begin{tabular}{|c|c|c|c|c|c|c|c|c|c|c|}
\hline & (1) & (2) & (3) & (4) & (5) & (6) & (7) & (8) & (9) & (10) \\
\hline Primary spending/GDP & $\begin{array}{c}-0.08^{* * *} \\
{[-3.3]}\end{array}$ & & & & & $\begin{array}{l}-0.04 \\
{[-1.1]}\end{array}$ & & & & \\
\hline Discretionary spending/GDP & & $\begin{array}{l}-0.08 \\
{[-0.5]}\end{array}$ & $\begin{array}{l}0.08 \\
{[1.3]}\end{array}$ & $\begin{array}{l}-0.02 \\
{[-0.3]}\end{array}$ & $\begin{array}{r}-0.10 \\
{[-1.2]}\end{array}$ & & $\begin{array}{l}-0.08 \\
{[-0.5]}\end{array}$ & $\begin{array}{l}0.06 \\
{[0.9]}\end{array}$ & $\begin{array}{r}-0.02 \\
{[-0.3]}\end{array}$ & $\begin{array}{l}-0.08 \\
{[-1.0]}\end{array}$ \\
\hline Automatic spending/GDP & & $\begin{array}{c}-0.11^{* * *} \\
{[-3.3]}\end{array}$ & & & & & $\begin{array}{l}-0.07 \dagger \\
{[-1.5]}\end{array}$ & & & \\
\hline $\begin{array}{l}\text { Automatic spending/GDP } \\
\text { (when unemployment insurance is absent) }\end{array}$ & & & $\begin{array}{l}0.14 \\
{[1.0]}\end{array}$ & & & & & $\begin{array}{l}0.04 \\
{[0.3]}\end{array}$ & & \\
\hline $\begin{array}{l}\text { Automatic spending/GDP } \\
\text { (when unemployment insurance is present) }\end{array}$ & & & $\begin{array}{c}-0.07^{* *} \\
{[-2.4]}\end{array}$ & & & & & $\begin{array}{c}-0.06^{* *} \\
{[-2.5]}\end{array}$ & & \\
\hline $\begin{array}{l}\text { Automatic spending/GDP } \\
\text { (when social security formula indexation is absent) }\end{array}$ & & & & $\begin{array}{l}0.04 \\
{[0.8]}\end{array}$ & & & & & $\begin{array}{l}0.05 \\
{[1.1]}\end{array}$ & \\
\hline $\begin{array}{l}\text { Automatic spending/GDP } \\
\text { (when social security formula indexation is present) }\end{array}$ & & & & $\begin{array}{c}-0.07^{* * *} \\
{[-3.7]}\end{array}$ & & & & & $\begin{array}{l}-0.05^{* *} \\
{[-2.3]}\end{array}$ & \\
\hline $\begin{array}{l}\text { Automatic spending/GDP } \\
\text { (when unemployment insurance and } \\
\text { social security formula indexation are both absent) }\end{array}$ & & & & & $\begin{array}{l}0.08 \\
{[0.7]}\end{array}$ & & & & & $\begin{array}{l}-0.07 \\
{[-0.5]}\end{array}$ \\
\hline $\begin{array}{l}\text { Automatic spending/GDP } \\
\text { (when unemployment insurance is present and } \\
\text { social security formula indexation is absent) }\end{array}$ & & & & & $\begin{array}{l}0.06+ \\
{[1.6]}\end{array}$ & & & & & $\begin{array}{l}0.03 \\
{[0.6]}\end{array}$ \\
\hline $\begin{array}{l}\text { Automatic spending/GDP } \\
\text { (when unemployment insurance is absent and } \\
\text { social security formula indexation is present) }\end{array}$ & & & & & $\begin{array}{c}0.00 \\
{[0.00]}\end{array}$ & & & & & $\begin{array}{l}-0.17 \\
{[-1.0]}\end{array}$ \\
\hline $\begin{array}{l}\text { Automatic spending/GDP } \\
\text { (when unemployment insurance and } \\
\text { social security formula indexation are both present) }\end{array}$ & & & & & $\begin{array}{c}-0.04+ \\
{[1.5]}\end{array}$ & & & & & $\begin{array}{r}-0.06+ \\
{[-1.5]}\end{array}$ \\
\hline Terms of trade volatility & & & & & & $\begin{array}{c}0.08^{* *} \\
{[2.4]}\end{array}$ & $\begin{array}{l}0.06 \dagger \\
{[1.6]}\end{array}$ & $\begin{array}{l}0.04 \\
{[1.1]}\end{array}$ & $\begin{array}{l}0.03 \\
{[0.8]}\end{array}$ & $\begin{array}{l}0.05 \\
{[1.0]}\end{array}$ \\
\hline Observations & 121 & 99 & 99 & 89 & 72 & 118 & 97 & 97 & 88 & 71 \\
\hline
\end{tabular}

Notes: See Appendices 1,3 , and 5 for definition and source of variables. Robust t-statistics are in square brackets. The weak-identification test is the first-stage $\mathrm{F}$ test of excluded instruments; the null hypothesis is that the model is weakly identified (i.e., the excluded instruments have a nonzero correlation with the endogenous regressors). The over-identification test is Hansen's $\mathrm{J}$ statistic; the null hypothesis is that the instruments are exogenous (i.e., uncorrelated with the error term). Constant term not reported. ${ }^{*},+,{ }^{*},{ }^{* *}$ and ${ }^{* * *}$ indicate statistical significance at the $20 \%, 15 \%, 10 \%, 5 \%$ and $1 \%$ levels, respectively. 
Table 3 (cont.). Cross-country regressions. Dependent variable is macroeconomic volatility measured by the standard deviation of annual real GDP growth

\section{Panel B (cont.). Using instruments}

\begin{tabular}{|c|c|c|c|c|c|c|c|c|c|c|}
\hline & (1) & (2) & (3) & (4) & (5) & (6) & (7) & (8) & (9) & (10) \\
\hline Overidentification test ( $p$-value) & & 0.62 & 0.27 & 0.70 & 0.43 & & 0.36 & 0.24 & 0.64 & 0.53 \\
\hline \multicolumn{11}{|l|}{ Weak identification tests ( $p$-value) } \\
\hline Primary spending/GDP & $1.5 \times 10^{-5}$ & & & & & $1.5 \times 10^{-5}$ & & & & \\
\hline Discretionary spending/GDP & & 0.01 & $5.8 \times 10^{-6}$ & 0.08 & $3.2 \times 10^{-14}$ & & 0.02 & $1.8 \times 10^{-5}$ & 0.11 & $3.4 \times 10^{-19}$ \\
\hline Automatic spending/GDP & & $1.3 \times 10^{-15}$ & & & & & $1.2 \times 10^{-14}$ & & & \\
\hline $\begin{array}{l}\text { Automatic spending/GDP } \\
\text { (when unemployment insurance is absent) }\end{array}$ & & & $8.9 \times 10^{-14}$ & & & & & $5.3 \times 10^{-14}$ & & \\
\hline $\begin{array}{l}\text { Automatic spending/GDP } \\
\text { (when unemployment insurance is present) }\end{array}$ & & & $2.7 \times 10^{-14}$ & & & & & $2.8 \times 10^{-13}$ & & \\
\hline $\begin{array}{l}\text { Automatic spending/GDP } \\
\text { (when social security formula indexation is absent) }\end{array}$ & & & & $1.6 \times 10^{-10}$ & & & & & $9.5 \times 10^{-11}$ & \\
\hline $\begin{array}{l}\text { Automatic spending/GDP } \\
\text { (when social security formula indexation is present) }\end{array}$ & & & & $5.1 \times 10^{-15}$ & & & & & $2.2 \times 10^{-12}$ & \\
\hline $\begin{array}{l}\text { Automatic spending/GDP } \\
\text { (when unemployment insurance and } \\
\text { social security formula indexation are both absent) }\end{array}$ & & & & & $2.9 \times 10^{-7}$ & & & & & $4.5 \times 10^{-21}$ \\
\hline $\begin{array}{l}\text { Automatic spending/GDP } \\
\text { (when unemployment insurance is present and } \\
\text { social security formula indexation is absent) }\end{array}$ & & & & & $3.2 \times 10^{-14}$ & & & & & $1.1 \times 10^{-27}$ \\
\hline $\begin{array}{l}\text { Automatic spending/GDP } \\
\text { (when unemployment insurance is absent and } \\
\text { social security formula indexation is present) }\end{array}$ & & & & & $9.0 \times 10^{-3}$ & & & & & $8.1 \times 10^{-3}$ \\
\hline $\begin{array}{l}\text { Automatic spending/GDP } \\
\text { (when unemployment insurance and } \\
\text { social security formula indexation are both present) }\end{array}$ & & & & & $4.8 \times 10^{-10}$ & & & & & $2.6 \times 10^{-25}$ \\
\hline
\end{tabular}

Notes: See Appendices 1, 3, and 5 for definition and source of variables. Robust t-statistics are in square brackets. The weak-identification test is the first-stage $F$ test of excluded instruments; the null hypothesis is that the model is weakly identified (i.e., the excluded instruments have a nonzero correlation with the endogenous regressors). The over-identification test is Hansen's $J$ statistic; the null hypothesis is that the instruments are exogenous (i.e., uncorrelated with the error term). Constant term not reported. ${ }^{*},+, *, * *$ and ${ }^{* * *}$ indicate statistical significance at the $20 \%, 15 \%, 10 \%, 5 \%$ and $1 \%$ levels, respectively. 
Table 4. Cross-country regressions. Dependent variables are primary spending/GDP, discretionary spending/(discretionary spending plus automatic spending), unemployment insurance dummy in recent times, and automatic price-based formula indexation mechanism in recent times

\begin{tabular}{lc}
\hline Panel A: Dependent variable is primary spending/GDP & \\
\hline & \\
Presidential (1) or parliamentary (0) dummy & $-0.13^{* * *}$ \\
& {$[-7.5]$} \\
Observations & 121 \\
$\mathrm{R}^{2}$ & 0.37 \\
\hline
\end{tabular}

Panel B: Dependent variable is

discretionary spending/(discretionary spending+automatic spending)

\begin{tabular}{lc}
\hline & \\
Old age dependency ratio & $-0.02^{* * *}$ \\
& {$[-11.6]$} \\
Observations & 102 \\
$\mathrm{R}^{2}$ & 0.45 \\
& \\
Panel C: Dependent variable is unemployment insurance & \\
dummy in recent times & \\
\hline
\end{tabular}

$\begin{array}{lc}\text { Unemployment insurance circa } 1970 & 0.72^{* * *} \\ & {[14.8]} \\ & \\ \text { Observations } & 125 \\ \mathrm{R}^{2} & 0.45\end{array}$

Panel D: Dependent variable is automatic price-based

formula indexation mechanism dummy in recent times

\begin{tabular}{lc}
\hline & \\
Automatic price-based formula indexation & $0.79^{* * *}$ \\
mechanism dummy at initial time & {$[14.5]$} \\
& \\
Observations & 110 \\
$\mathrm{R}^{2}$ & 0.64
\end{tabular}

Notes: See Appendices 1, 3, and 5 for definition and source of variables. Robust t-statistics are in square brackets. Constant term not reported. ${ }^{*}$, $+, *, * *$ and ${ }^{* * *}$ indicate statistical significance at the $20 \%, 15 \%, 10 \%, 5 \%$ and $1 \%$ levels, respectively. 